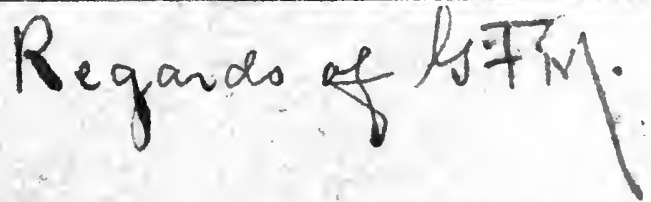

THE COVENANTERS OF DAMASCUS; A HITHERTO UNKNOWN JEWISH SECT

GEORGE FOOT MOORE

Reprinted from

THE HARVARD THEOLOGICAL REVIEW Volume IV

July, 1911 


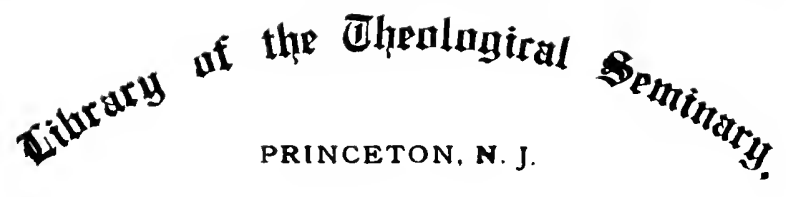

BV 175 . C6 M66 1911

Moore, George Foot, 1851.-

1931.

The covenanters of Damascus 
, 


\title{
THE COVENANTERS OF DAMASCUS; A HITHERTO UNKNOWN JEWISH SECT'1
}

\author{
GEORGE FOOT MOORE
}

Harvard UNIVERsity

Among the Hebrew manuscripts recovered in 1896 from the Genizah of an old synagogue at Fostat, near Cairo, and now in the Cambridge University Library, England, were found eight leaves of a Hebrew manuscript which proved to be fragments of a book containing the teaching of a peculiar Jewish sect; a single leaf of a second manuscript, in part parallel to the first, in part supplementing it, was also discovered. These texts Professor Schechter has now published, with a translation and commentary, in the first volume of his Documents of Jewish Sectaries. The longer and older of the manuscripts (A) is, in the opinion of the editor, probably of the tenth century; the other (B), of the eleventh or twelfth.

What remains of the book may be divided into two parts. Pages 1-8 of $A$, and the single leaf of $B$, contain exhortations and warnings addressed to members of the sect, for which a ground and motive are often sought in the history of the Jewish people or of the sect itself, together with severe strictures upon such as have lapsed from the sound teaching, and polemics against the doctrine and practice of other bodies of Jews. The second part, pages $9-16$, sets forth the constitution and government of the community, and its distinctive interpretation and application of the law,-what may be called sectarian halakah.

Neither part is complete; the manuscript is mutilated and defective at the end, there is apparently a gap between the first and second parts, and it may be questioned whether the original beginning of the work is preserved. The lack of methodical arrangement in the contents leads Dr. Schechter to surmise that

${ }^{1}$ Documents of Jewish Sectaries. Volume I. Fragments of a Zadokite Work. Edited, with Translation, Introduction, and Notes, by S. Schechter. Cambridge University Press. 1910. 
what we have in our hands is only a compilation of extracts from a larger work, put together with little regard for completeness or order. An orderly disposition, according to our notions of order, is not, however, so constant a characteristic of Jewish literature as to make this inference very convincing.

Manuscript A was evidently written by a negligent scribe, perhaps after a poor or badly preserved copy; B, which represents a somewhat different recension of the work, exhibits, so far as it goes, a superior text. When it is added that both manuscripts are in many places defaced or torn, it may be imagined that the decipherment and interpretation present serious difficulties, and that, anter all the pains which Dr. Schechter has spent upon the task, many uncertainties remain. Facsimiles of a page of each manuscript are given; but in view of the condition of the text a photographic reproduction of the whole is indispensable.

The legal part of the book, so far as the text is fairly well preserved, is not exceptionally difficult: the rules are in general clearly defined, and if in the peculiar institutions of the sect there are many things we do not fully understand, this is due more to the brevity with which its organization is described and to the mutilation of the text than to lack of clearness in the description itself. The attempt to make out something of the history and relations of the sect from the first part of the book is, on the other hand, beset by many difficulties. What history is found there is not told for the sake of history, but used to point admonitions or emphasize warnings; and, after the manner of the apocalyptic literature, historical persons and events are referred to in roundabout phrases which envelop them in an affected mystery. Even when such references are to chapters of the national history with which we are moderately well acquainted, as in the Assumption of Moses, c. 5, ff., for example, they may be to us baffling enigmas; much more when they have to do, as is in large part the case in our texts, with the wholly unknown internal or external history of a sect. The obscurity is increased by the fact that the allusions are often a tissue of fragmentary quotations or reminiscences out of the Old Testament, chosen and combined, it seems, by purely verbal association, or taken in an occult allegorical sense. ${ }^{2}$ The

2It may be added that the quotations are singularly inexact. 
allegories of which an interpretation is given, as when Amos 5 $26 \mathrm{f}$. is applied to the emigration to Damascus and the institutions and laws of the sect, and Ezekiel 4415 to the classes of the community, do not encourage us to think that we should be able to divine the meaning by our unaided intelligence. It is a fortunate circumstance that the writer comes back more than once to the salient events in the sect's history, for these repetitions of the same thing in different forms afford considerable help to the interpreter, so that the main facts may be made out with at least a considerable degree of probability.

The principal seat of the sect was in the region of Damascus, where its adherents formed numerous communities. It was composed of Israelites who had migrated thither from Judaea; thither also had come "the interpreter of the law," the founder of the sect; there it had been organized by a covenant repeatedly referred to as "the new covenant in the land of Damascus." Many who entered into this new covenant at the beginning did not long remain true to it; the writer inveighs vehemently against those who fell away, accusing them not only of grave error, but of gross violations of the law; but this crisis had been passed, and when the book was written the community was apparently flourishing.

The most coherent account of the origin of the sect is found on pages $5-6:^{3}$

At the end of the devastation of the land arose men who removed the boundary and led Israel astray; and the land was laid waste because they spoke rebelliously against the commandments of God by Moses and also against his holy Anointed, ${ }^{4}$ and prophesied falsehood to turn Israel back from following God. But God remembered the covenant with the forefathers, and he raised up from Aaron discerning men and from Israel wise men, and he heard them, and they dug the well. "The well, princes dug it, nobles of the people delved it, with the legislator" (Numbers 21 18). The well is the law, and they who dug it are the captivity of Israel ${ }^{5}$ who went forth from the land of Judah and sojourned in the land of

${ }^{3}$ In my translation I have sometimes thought it possible to adhere to the text where Dr. Schechter has preferred a conjectural emendation.

${ }^{4}$ That is, probably, against the legitimate high priest of the time (perhaps Onias).-The rendering " $b y$ his Anointed" is grammatically admissible, but would be unintelligible in this context.

${ }^{5}$ It would be possible to render "the penitents of Israel." 
Damascus, all of whom God called princes because they sought him. ${ }^{6}$. . . The legislator is the interpreter of the law, as Isaiah said, "Bringing forth a tool for his work" (Isa. 54 16), and the nobles of the people are those who came to delve the well with the statutes which the legislator decreed that men should walk in them in the complete end of wickedness; and besides these they shall not obtain any (statutes) until the teacher of righteousness shall arise in the last times.

The migration is referred to in several other places: "The captivity of Israel, who migrated from the land of Judah" (4 \& f.) $;{ }^{7}$ "those who held firm made their escape to the northern land," by which the region of Damascus is meant $(713 \mathrm{f}$; cf. $7 \mathbf{1 5}, 18 \mathrm{f}$.). The time of the migration is plainly indicated in the passage quoted above ( $520 \mathrm{ff}$.). The men who, after the end of the devastation of the land, "removed the boundary," and led Israel astray, speaking rebelliously against the commandments of God by Moses and against his holy Anointed, prophesying falsely to turn Israel away from following God, in consequence of which the land was laid waste, are most naturally taken for the hellenizing leaders of the Seleucid time. In this period, it seems that a number of Jews, including priests and levites, withdrew to the region of Damascus, ${ }^{8}$ and there they subsequently bound themselves by covenant to live strictly in accordance with the law as defined by their legislator.

With this the other allusions agree. Thus in A, p. 8 (=B, p. 19 ), at the end of a violent invective against the sinners, of whom it is said, "The princes of Judah are like those who remove the boundary," we read that "they separated not from the people [and their sins, B], but presumptuously broke through all restraints, walking in the way of the wicked (heathen), of whom God said, 'The venom of dragons is their wine, and the head of asps is cruel' ' (Deut. 32 33). The dragons are the kings of the nations, and their wine means their ways, and the head of asps is the head of the Greek kings who came to inflict vengeance upon them." This again is most naturally understood of Antiochus

6 The four or five words which follow are unintelligible.

${ }^{7}$ The references are to page and line of the Hebrew text.

${ }^{8}$ Others sought refuge in Egypt; the temple of Onias at Leontopolis had its origin in the same circumstances.

${ }^{9}$ So they understood the words translated in the English version "the cruel venom of asps." 
Epiphanes; the calamities he brought on the Jews were a direct consequence of the course of the hellenizing party..$^{10}$

A definite date for these occurrences is given in $15 \mathrm{ff}$.: "When God's wrath was over, three hundred and ninety years after he gave them into the power of Nebuchadnezzar, king of Babylon, he visited them, and caused to spring up from Israel and Aaron a root of his planting to inherit his land and to thrive on the good things of his earth. And they recognized their wickedness and knew that they were guilty men, and they were like blind men and like men groping their way for twenty years. And God took note of their deeds, that with perfect heart they sought him, and he raised up for them a teacher of righteousness to guide them in the way of his heart."

The "root" which God, mindful of his covenant, caused to spring up from Aaron and Israel is the men with whom the religious revival, or reformation, began, the forefathers of the sect. (see $6 \& \mathrm{f}$., and below, p. 375); "11 the "teacher of righteousness" is the "interpreter of the law who came to Damascus" (6 7 f., 718 f.). The dates refer therefore to the origin of the sect. Three hundred and ninety years from the taking of Jerusalem by Nebuchadnezzar (597 or 586 B.c.) would bring us, by our chronology, to 207 or 196 B.c. The Jewish chronology of the Persian period is, however, always too long by from forty to seventy years, ${ }^{12}$ and assuming, as it is fair to do, that our author made the same error, the three hundred ninety years would run out in the middle of the third century. Dr. Schechter suspects, with much probability, that the original reading was "four hundred and ninety years," the common apocalyptic cycle (Dan. 9 \&, 24; Enoch 89-90; 93, etc.). Making the same allowance for error, we should be brought again to a time not far removed from the pun-

${ }^{10}$ See 2 Macc. 4 16: "By reason of which (sc. their predilection for Greek ways) a dire calamity befel them, and those for whose customs they displayed such zeal and whom they wanted to imitate in everything became their enemies and avengers." Assumption of Moses, 5 1: "When the times of retribution shall draw near, and vengeance arises through kings who share their guilt and punish them," etc., describes the same situation.

${ }^{11}$ Cf. "the whole race of the elect root," Enoch 938.

${ }^{12}$ See Schürer, Geschichte des jüdischen Volkes (3 ed.), vol. iii, p. 189. 
ishment inflicted on the people by Antiochus Epiphanes (see above, p. 333 f.). ${ }^{13}$

There is nothing in the texts which demands a later date for the origin of the sect. The last event in the national history to which reference is made is the vengeance inflicted on the heathenizing rulers of the people by "the head of the Greek kings." To the misfortunes of the people in the following centuries, such as the taking of Jerusalem by Pompey or its destruction by Titus, there is no allusion. It may perhaps be inferred not only that the schism antedated these calamities, but that the book was written before them. In the author's frame of mind toward the religious leaders of Palestinian Jewry, he would have been likely to record such conspicuous judgments upon them. A comparison with the Assumption of Moses is instructive on this point. There the sweeping denunciation of the priesthood and the scribes, "their teachers in those times," and of the godless Asmonaean priest-kings, is followed by the well-deserved judgment inflicted on them by Herod, and after him comes Varus, burning part of the temple, crucifying, and carrying off into slavery. The second of the Psalms of Solomon may also be compared.

The schismatic character of the sect would also be explained

${ }^{13}$ A comparison with the Apocalypse of the Ten Weeks in Enoch (93+ 91 12-17) is in point here. The sixth "week" (period of 490 years) ends with the destruction of the temple by Nebuchadnezzar; in the seventh a rebellious generation arises, all whose works are apostasy (the hellenizers of the Seleucid time); at its end the "chosen righteous men of the eternal plantation of righteousness" are chosen to receive the sevenfold instruction about God's whole creation (apparently the cosmological revelations of Enoch); the historical retrospect closes before the robbery and desecration of the temple by Antiochus Epiphanes $(170,168$ в.c.), of which the seer knows nothing. The chronological error here amounts to sixty or seventy years.

In the Introduction, p. xii, by a typographical error which is repeated on p. xxii, Dr. Schechter says that the 390 years of the text would bring us "to within a generation of Simon the Just, who flourished about 290 в.c.," and twenty years more would bring us into the midst of the hellenistic persecutions preceding the Maccabaean revolt (about 170 B.c.). Margoliouth, whose hypothesis 490 does not suit any better than 390 , takes courage from Schechter's doubts to disregard the numbers altogether. Gressmann (Internationale Wochenschrift, March 4, 1911) is led by metrical considerations to treat all the chronological notices as interpolations, and gives them no further consideration. But even if the figures were introduced by a later hand, they may still represent the tradition of the sect. 
if it arose in an age when the character of the political and religious heads of the Jewish people was such as to move God-fearing and law-abiding men to repudiate them with all their ways and works. For it is not merely with a sect, differing from the mass of their fellows in certain opinions and practices, that we have to do, but with a schism. The Covenanters of Damascus are radical come-outers, seceders not only from the land of Judaea, but from established Judaism, on which they look much as the Puritan Separatists in the seventeenth century looked on the English Church; they night have taken to themselves the prophetic word so often in the mouth of the Puritan, "Depart ye, depart ye, go ye out from thence, touch no unclean thing; go ye out of the midst of her; be ye clean, ye that bear the vessels of the Lord" (Isa. 52 11), as they do apply to the religious teachers of the Jewish church the most violent invectives of the same prophet $(5011$, $594 \mathrm{ff}$.; see below, p. 344f.). They will not even call themselves Jews, they are Israelites who went forth from the land of Judaea; their Messiah is to spring from Aaron and Israel, not from Judah; when the final judgment comes in its appointed time, it will no longer be permitted to make compact with the house of Judah, but every man must stand in his own stronghold; ${ }^{14}$ when the glory of God shines out on Israel, all the wicked of Judah shall be cut off, in the day of its trial by fire. They reject the temple in Jerusalem, and will not offer on its altar. If we consider that the Essenes, notwithstanding their wider divergence from the common type of Judaism, seem to have regarded themselves as within the pale of the church, and to have been so regarded by others-enjoying, indeed, with the people the reputation of peculiar sanctity - the schismatic character of our sect appears in a still stronger
light.

The language of the book is not inconsistent with the age to which the contents would seem to assign it. The vocabulary is in the main Biblical, but there are a number of words which otherwise occur only in the writings of the Mishnic age or later. Some of these belong to the technical terminology of the law schools, some of them appear to be peculiar to the sect. A few of the Biblical words also are used in later senses and applications.

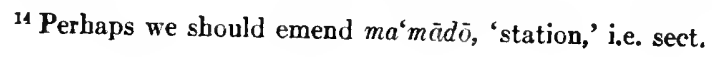


It is proper to bear in mind, however, that the Hebrew originals of the works with which it would be most natural to compare our text, such as Enoch, the Book of Jubilees, the 'Testaments of the Twelve Patriarchs, the Gospel, are not preserved; in fact, between the last books of the OId Testament and the rabbinical literature of the second Christian century there is a hiatus in the history of the Hebrew language, so that words which appear for the first time in the Mishna and kindred works may have been, and in many cases probably were, in use much earlier. It is unnecessary therefore to suppose that such words were introduced into our texts by later scribes, though the possibility of such changes must of course be admitted. The particular instances in which Dr. Schechter thinks that late and foreign influences are most clearly to be recognized-the title of the "censor" and the peculiar name for a house of worship-are discussed elsewhere..$^{15}$ More remarkable than the vocabulary of the book is its syntax. The consecutive constructions of the perfect and the imperfect are regularly employed, net only in imitation of Biblical models in narrative and prophetic passages, but in the legal part of the book; and in spite of some irregularities, which may in part at least be laid to the charge of scribes, the use of these tenses is generally correct. In this respect the Hebrew of the book differs entirely from that of the Mishna and the contemporary and later Midrashim, in which the characteristic features of classical tensesyntax have entirely disappeared, under the influence, it is generally supposed, of the Aramaic vernacular. In comparison with these writings the vocabulary also is notably free from foreign admixture. There are no words borrowed from Greek and Latin, and only one or two instances where an Aramaic term seems to have been adopted. The orthography also, in its more sparing use of the semivowels to indicate the vowels $u$ and $i$, resembles that of the Bible.

The founder of the sect is called the "teacher of righteousness" (1 11), 16 "the only, or beloved, teacher" ( $\left(\begin{array}{lll}20 & 14\end{array}\right) ; 17$ "the only

${ }^{15}$ See below, p. 350, $354 \mathrm{f}$.

${ }^{10} \mathrm{Cf}$. Isa. $3020 \mathrm{f}$.

${ }^{17}$ The Septuagint renders yāhid most frequently by $\dot{a} \gamma a \pi \eta \tau b s$, less often by

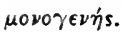


one" (20 32); he is "the legislator," that is, "the interpreter of the law" ( 67 7); and this interpreter of the law, who came to Damascus, is the star who, according to Balaam's prophecy, was to issue from Jacob ( 7 18 f.). ${ }^{18}$ He showed them how to walk in the way of God's heart (1 11); as interpreter of the law he ordained them statutes to walk in till the end of wickednessstatutes which shall not be superseded by any others "until there arise the teacher of righteousness in the last days" ( $611 \mathrm{f}$.). To him, therefore, are attributed the distinctive principles and observances of the sect as they are set forth in this book. "His anointed," through whom God made known to men his holy spirit, and who is true ( 212 f.), is in all probability the same person with the teacher, the star, just as the anointed from Aaron and Israel who is to arise in the future $\left(\begin{array}{ll}20 & 1\end{array}\right)$ is the same as the teacher of righteousness to whose voice they will then listen (20 32; see below, p. 343).

Those of the emigrants who accepted the guidance of the teacher of righteousness, the interpreter of the law, entered into the "new covenant in the land of Damascus" (6 19, 8 21, $1933 \mathrm{f}$., 90 12). The idea of the "new covenant" was doubtless suggested by Jer. $3131 \mathrm{ff}$. (cf. $3236 \mathrm{ff}$; Ezek. 37 26, etc.), where the establishment of the new covenant, in the stead of the old covenant which their fathers broke, marks the restoration of God's favor, the beginning of a new and better time. The same use of the passage in Jeremiah is made at length by the author of the Epistle to the Hebrews ( 86 ff.). The substance of the covenant may be gathered from 6 11-7 5 :

All who were brought into the covenant are not to enter into the sanctuary to light its altar, but became closers of the door, as God said, "Who among you will close its door?" and "Thou shalt not light my altar in vain" (Mal. 110$) ;{ }^{19}$ but shall observe to do according to the interpretation of the law for the end of wickedness, and to separate from the children of perdition, and to keep aloof from unrighteous gain, which is unclean by vow and ban, ${ }^{20}$ and from the property of the sanctuary, and from

${ }^{18}$ The same prophecy which was applied by Akiba to Bar Cocheba and by the Dositheans to their founder (see below, p. 362).

${ }^{19}$ The sect rejects the temple in Jerusalem and its worship. Cf. $2021 \mathrm{f}$, in the last crisis, "they will lean upon God . . . and will declare the sanctuary unclean and will return to God."

${ }^{20}$ Perhaps better, keep aloof, by vow and ban, from unrighteous, unclean gain. 
robbing the poor of the people and making widows their spoil and murdering orphans; and to separate between the unclean and the clean, and to show the difference between the holy and the common; and to observe the Sabbath day as it is defined, and the season feasts, and the fast-day, in accordance with the commandments of those who entered into the new covenant in the land of Damascus; to set apart the sacred dues as they are defined; and that a man should love his neighbor as himself, and sustain the poor and needy and the proselyte, and to seek each the welfare of the other; and that no man transgress the prohibited degrees, but guard against fornication according to the rule; and that a man should reprove his brother according to the commandment, and not bear a grudge from day to day; and to separate from all forms of uncleanness according to their several prescriptions; and that a man should not defile his holy spirit, even as God separated for them (sc. unclean from clean). All who walk in these precepts in perfection of holiness, according to all the foundations of the covenant of God, ${ }^{21}$ have the assurance that they shall live a thousand generations.

Early in the history of the sect a serious defection occurred. Men who entered among the first into the covenant incurred guilt, like their forefathers, by following their sinful inclinations; they forsook the covenant of God and preferred their own will, and went about after the stubbornness of their heart, every man doing as he pleased ( $310 \mathrm{ff}$.); the men who entered into the new covenant in the land of Damascus went back and proved false, and turned aside from the well of living waters (19 $33 \mathrm{i}$.). Their names were struck out of the registers of the sect, as were those of such as fell away in later times.

We can readily imagine that many found the rule of the sect too strict and the discipline by which it was enforced too severe. Our texts, however, speak not of such occasional and individual lapses, but of the repudiation of the covenant by numbers at one time. It seems that another leader had arisen, of very different temper from the founder, who drew away many after him. In the eyes of those who remained steadfast in the faith, the new teacher was naturally a false prophet, a kind of antichrist. $\mathrm{He}$ is called the liar ("the man of lies," 2015 ), the scoffer (1 14); his adherents are scoffers, ${ }^{22}$ who uttered error about the righteous

${ }^{21}$ See below, p. 353.

${ }_{22}$ The name comes from Isa. 28 14, where the scorners are the rulers in Jerusalem, who boast of their covenant with death and their compact with hell, who have made lies their refuge and hidden themselves in falsebood. See also Isa. 2920. 
statutes, and spurned the covenant and plighted faith which they established in the land of Damascus, that is to say, the new covenant. They and their families shall have no portion in the house of the law ( $2010 \mathrm{ff}$.). For their unfaithfulness they were delivered to the sword ( $310 \mathrm{ff}$.), until of all the men of war who went with the liar none was left $(2014 \mathrm{ff}.) .{ }^{23} \quad$ This came to pass about forty years after the death of the unique teacher $(l . c$.$) . If$ the emigration to Damascus occurred under Antiochus Epiphanes, ${ }^{24}$ the end of the episode of the false prophet would fall about the beginning of the first century B.c., and we should have at least an upper limit for the writing of the book. The passion which every mention of this defection arouses suggests that it was fresh in memory, and would incline us to date the writing not very long after the time indicated. It should be observed, however, that the sentence which counts forty years from the death of the unrivalled teacher to the end of the liar's army sits loose in the context, and may be a gloss, in which case the book might be some decades older.

With the remnant who remained faithful through the great defection "God confirmed his covenant with Israel forever, revealing to them the secret of things in which all Israel was in error, his holy Sabbaths and his glorious festivals and his righteous testimonies and his true ways and the pleasure of his will, things which if a man do he shall live by them. He opened a way before them, and they dug a well for copious waters." "In the abundance of his wonderful grace he atoned for their guilt and forgave their transgression, and built for them a sure house in Israel, the like of which did not arise in times past nor until now" (3 1220). The prediction of the sure house (1 Sam. 235 ) seems to be fulfilled in the stability of the sect itself, or perhaps, with closer adherence to the prophecy, in that of its faithful priesthood.

So much may be gathered from the book about the origin and history of the sect. We turn now to its expectation. As a teacher of righteousness, an anointed one (priest), was the founder of the sect, so in the last times a teacher of righteousness, an

${ }^{23}$ It might be surmised that the false prophet had headed an insurrectionperhaps a Messianic rising-which ended in disaster.

${ }^{24}$ See above, p. 333. 


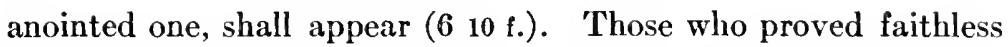
to the covenant are cut off from the community, "from the time when the unique teacher was taken away until the anointed one from Aaron and Israel shall arise" (19 35-20 1), that is, during the whole of the present dispensation. Dr. Schechter regards the anointed one who is to appear in the future as the founder of the sect redivivus: the present dispensation "seems to be the period intervening between the first appearance of the Teacher of Righteousness (p. 1, l. 11) (the founder of the Sect), who was gathered in or died, ${ }^{25}$ and the second appearance of the Teacher of Righteousness who is to rise in 'the end of the days' (p. 6, l. 11). Moreover, the Only Teacher, or Teacher of Righteousness, is identical with the Messiah, or the Anointed one from Aaron and Israel, whose advent is expected by the Sect." ${ }^{26}$ The texts, however, say nothing of the disappearance, or a second appearance, or reappearance, or return of the founder; nor do the words "until the teacher of righteousness shall arise in the last days," "until the anointed shall arise from Aaron and Israel," mean that he shall rise from the dead, as Dr. Schechter interprets them. ${ }^{27}$ The Messiah whose advent the sect expects at the end of the present period of history is, as in the older parts of the Testaments of the Twelve Patriarchs, a priest; and the function of the priestmessiah is not, as in the Epistle to the Hebrews, to mediate between man and God, but to instruct men in righteousness, to guide them in the way of God's heart. That the founder of the sect also was both priest and teacher is by no means sufficient to establish the identity of the two figures. It was the office of the priest to teach Israel the law, "all the statutes which the Lord hath spoken unto them through Moses" (Lev. 10 11; cf. Deut. 33 10); “the priest's lips should keep knowledge, and they should seek

$250 r$, as Schechter elsewhere expresses it, "disappeared." Among the synonyms for death, Aaron ben Eliahu names "gather in" (Isa. 58 s).

${ }^{26}$ Introduction, p. xiii.

${ }^{27}$ P. xiii. "We gather from another passage that the Only Teacher found his death in Damascus, but is expected to rise again (p. 19, 1. 35; p. 20, 1. 1; cf. also p. 6, 1. 11)." The verb "amad means, as frequently in the later books of the Old Testament, 'appear upon the scene.' In this sense it occurs repeatedly in the book before us, and there is nothing in the context here to suggest a different interpretation. 
the law at his mouth, for he is the messenger of the Lord of Hosts" (Mal. 2 7). Ezra is the type of a priest who had not only prepared his heart to seek the law of the Lord and to do it, but to teach in Israel statutes and judgments (Ezra 7 10); he was, according to the books of Ezra and Nehemiah, the restorer of Judaism. It was a departure from the ideal of the law itself that, when the priesthood showed itself unworthy of its calling, the teaching function was assumed by lay scribes, and even in later times there were many priestly teachers among the Scribes and among the Doctors. That our sect looks back to one such as its founder, and forward to another as the great teacher of the Messianic age, is in no way surprising. If the author had meant what Dr. Schechter thinks, it is fair to assume that he would have said it unmistakably; for the identity of the expected Messiah with the dead founder, if it was part of the belief of the sect, would of necessity be a singular and significant part of it. ${ }^{28}$

The coming judgment of God is represented rather as a judgment on the faithless members of the sect, including those who have seceded from it or been expelled, than in its more general aspects. The long eschatological passage in B (2015 to the end) is illegible in spots near the beginning, but the general tenor is clear:

In that consummation the anger of God will be inflamed against Israel, as he said, "There is no king and no prince, and no judge and none that reproves in righteousness" (cf. Hos. 34 ). Those who turn from the transgression [of Jacob] ${ }^{29}$ and keep the covenant of God will then confer with one another; their footsteps will be firm in the way of God (and the prophecy will be fulfilled which says), "And God hearkened to their words and heard, and a book of remembrance was written before him for those that fear God and think on his name" (Mal. 3 16), until deliverance and righteousness emerge for those that fear God, "and ye shall return and see the difference between righteous and wicked, and between a servant of God and one who serves him not" (Mal. 3 18). And he shows favor to those that love him and keep his commandments, for a thousand generations. ${ }^{30} \ldots$

${ }^{28} \mathrm{Cf}$. Acts 111.

29 See Isa. 5920.

${ }^{30}$ The quotation is to be thus restored; see Exod. 206 and Deut. 79 . The nert two or three lines are very obscure: "From the house of Peleg, who went out (or, will go out) from the city of the sanctuary, and they will rely on God 
Each man according to his spirit, shall they be judged by his holy counsel, and all who have broken through the bounds of the law, of those who entered into the covenant, when the glory of God shines out on Israel, shall be cut off from the midst of the camp, and with them all the evil-doers of Judah, in the days when it is tried in the fire. But all who held firmly by these precepts, going out and coming in in conformity with the law, and listened to the voice of the teacher, will confess "1 before God.... "We have done evil, we, and our fathers also, when they went contrary to the statutes of the covenant, and faithful are thy judgments upon us." And they will not act presumptuously against his holy statutes and his righteous judgment and his faithful testimonies. They will be instructed in the ancient judgments by which the followers of the unique one were judged, and will hearken to the words of the teacher of righteousness. And they will not controvert the righteous statutes when they hear them; they will rejoice and be glad, and their heart will be strong, and they will show themselves mighty against all the people of the world. ${ }^{32}$ And God will atone for them, and they will see his salvation with joy, because they trusted in his holy name.

Here the fragment ends. The destruction of those who fall away from the sect is threatened in other places; it will suffice to quote the most important (19 5 ff.):

Upon all those who reject the commandments and the statutes, the deserts of the wicked shall be requited when God visits the earth, when the word comes to pass which was written by Zechariah the prophet, "Sword, awake against my shepherd and against the man that is my fellow, saith God; smite the shepherd, and let the sheep be scattered, and I will turn my hand against the little ones" (Zech. 13 7). But those who observe it (sc. the obligations of the covenant) are "the poor of the flock" (Zech. 11 7). These shall escape at the end of the visitation, but the former (sc. those who reject the commandments) shall be given over to the sword when the Anointed of Aaron and Israel comes, as it was at the end of the first visitation, of which God said by Ezekiel that a mark should be made on the foreheads of them that sigh and cry,

(cf. Isa. 1020 ) when the transgression of Israel is at an end, and will declare the sanctuary unclean, and will return to God. The prince (?) of the people with few words (??)." The house of Peleg may be an etymological allegory for the seceders; the city of the sanctuary is probably Jerusalem (cf. $611 \mathrm{ff}$., above, p. 338); but neither the connection with the preceding nor the meaning of the sequel is clear.

${ }^{31}$ Text, "and confessed," which leaves the sentence without a predicate.

${ }^{22}$ See also 7 20: "The sceptre" (Num. 24 17) "is the prince of all the congregation; and when he arises he will destroy all the children of Seth." 
and the rest were delivered to the sword that executes the judgment of the covenant. And so shall the judgment be of all who enter into his covenant and do not hold firmly by these statutes, they shall be visited even with extermination by the hand of Belial. This is the day in which God will visit, as he spoke, "The princes of Judah are become like men who remove the boundary; on them will I pour out my fury like water" (Hos. 5 10). For they entered into the covenant of repentance, but did not turn aside from the way of faithless men, and wallowed in ways of fornication and in unrighteous gain, and avenging themselves and bearing a grudge against one another.

It is possible, of course, that the judgment of the heathen world, which looms so large in most of the apocalypses, may have had a place in parts of the book now lost, but if it had been a very important feature in the expectation of the sect we should hardly fail to find at least allusions to it in the pages in our hands. The author is almost exclusively interested in the sect itself, in the division which had rent it, and in polemics against laxer interpretations of the law. This limitation of the horizon is characteristically sectarian, and may suggest, moreover, as has been said above, that the writer is not far removed in time from the split in the new organization.

The polemic is especially pointed against certain opponents who are described as "those who build a wall and plaster it with stucco" (4 19; 8 12)..$^{33}$ They follow a commandment (sau); probably connoting, as in Hosea 511 , from which the phrase is taken, an arbitrary rule of their own, a commandment of men. ${ }^{34}$ God hates them, his anger is kindled against them $(8$ 18). These "builders" are false teachers; Biblical denunciations of the false prophets are applied to them. (See especially $812 \mathrm{f}$.) Points in which their teaching is particularly assailed are that they allow polygamy and the remarriage of divorced persons during the life of the other party, and hold it lawful for a man to marry his niece;

${ }^{33}$ It is not improbable that the author thought also of the other meaning of the word täphēl, here rendered 'stucco,' viz. something insipid, stupid; cf. Lam. 214 , in a passage which, like Ezek. 1310 , refers to the false prophets. I see nothing to indicate that "the wall" is the fence or hedge which the Pharisaean rabbis drew around the law to protect it from infraction, as Dr. Schechter thinks.

${ }^{34}$ The text explains, "this is the prater of whom it says, they prate unceasingly" (4 19 f.; cf. Mic. 211 ). Dr. Schechter regards this explanation as "a disturbing parenthesis." 
that they defile the sanctuary by the laxity of some of their rules and practice about sexual uncleanness; they presume blasphemously to impugn the "statutes of the covenant of God" (the legislation of the sect), declaring that they are not right, and saying abominable things about them (4 20-5 14). The positions so hotly denounced, especially in the matter of marriage and divorce, are those of the Palestinian rabbis as we know them in the Mishna and kindred works, and in so far as the Pharisees had a dominating influence in the schools of the law they may be regarded as in a peculiar sense the object of this invective, which is, however, sweeping enough to include all rabbinical Judaism. Such verses as Isaiah 50 11 and 59 4 ff. are hurled at them; they are compared to Johanneh and his brother, whon Belial raised up against Moses $\left(\begin{array}{lll}5 & 17 & \mathrm{ff} .\end{array}\right)^{35}$

The sect prohibited polygamy, which they stigmatized as fornication, arguing from the creation - "a male and a fenıle created he them" (cf. Matt. 194 ), and from the story of the flood- "by pairs they went into the ark," and from the law which forbade the prince to multiply wives unto himself (Deut. 17 17), that is, as they understood it, to take more than one wife. To forestall an objection, it is added: "But David had not read in the sealed book of the law which was in the ark, for it was not opened in Israel from the time of the death of Eleazar and Joshua and the elders who worshipped the Astartes, but was hidden and not brought to light until Zadok arose” (5 q-5; see below, p. 359).

Marriage with another woman while a man had a divorced wife living was apparently put in the same category with having two wives at the same time (4 20 f.; cf. Matt. 5 31 f.). Marriage with a niece (brother's or sister's daughter) they treated as incest, reasoning that marriage between a woman and her uncle stood on all fours with marriage between a man and his aunt, which was expressly forbidden as within the prohibited degrees of kinship. ${ }^{36}$ The three snares of Belial by which he ensnared Israel

${ }^{35}$ The Jannes and Jambres of 2 Tim. 38.

${ }^{36}$ Such marriages, especially with a sister's daughter, are not only permitted, but especially commended in the Talmud (Yebamoth $6 \mathrm{gb}-63 \mathrm{a}$; see Maimonides, Issure Biah $\& 14$ ), and are still common in countries where the Jews are free to follow the rabbinical law. On the Karaite prohibition of marriage with a niece, see below, p. 366 . 
are fornication (that is, plural or incestuous unions), wealth (that is, unrighteous gain), and the pollution of the sanctuary (4 $15 \mathrm{f}$; cf. 5 G f.)..$^{37}$

The same rigorous tendency which appears in the attitude of the sect in regard to marriage pervades the whole legal part of the work before us. The rules for the observance of the Sabbath (10 14-11 21) will make this clear.

Concerning the Sabbath, to keep it as it is preseribed.

1. On the sixth day no man shall do any work from the time when the disk of the sun is distant from the western portal ${ }^{38}$ by its diameter (?); for this is what he said: Observe the Sabbath day to hallow it.

2. On the Sabbath a man shall not engage in any foolish conversation; and he shall not exact repayment from his neighbor; nor shall he give judgment in matters of property; he shall not talk about matters of work and labor to be done on the next day.

3. A man shall not walk in the country to do the work of his business on the Sabbath. He shall not walk outside of his town above one thousand ${ }^{39}$ cubits.

4. No man shall eat on the Sabbath anything except what was previously prepared or what is spoiling in the field. He shall not eat or drink anything but what was in the camp. If he be on the way and descend to bathe, he may drink as he stands, but must not draw water in any ressel. ${ }^{40}$

5. He must not send a foreigner to do his business on the Sabbath day.

6. A man must not put on soiled garments or such as are brought by a gentile, without washing them in water or rubbing them with frankincense. ${ }^{41}$

7. A man shall not exchange pledges ${ }^{42}$ of his own accord on the Sabbath.

8. A man shall not follow his cattle, to pasture them outside his town, except within 2000 cubits. He shall not lift his arm to strike them with his fist; if the animal is breachy, let him not take her out of the house.

9. A man shall not take anything out of a house into the street, nor

${ }^{37}$ On the pollution of the sanctuary, cf. Assumption of Moses 5 3; Testament of Levi $145 \mathrm{ff}$; Psalms of Solomon 23 .

${ }^{38}$ On the portals of the sun, sce Enoch 72 , etc.

${ }^{39}$ Perhaps an error of the text for 2000 ; see below, $\S 8$.

${ }^{40} \mathrm{Cf}$. Jubilees 508.

${ }^{41}$ This holds on week-days as well as on the Sabbath.

${ }^{42}$ Perhaps we should read, "make an "erūb" (a legal fiction by which dwellings or limits were treated as one). The Sadducees and Samaritans rejected this evasion of the law. 
bring anything from the street into the house; and if he be in the entry, he shall not pass anything out of it or bring anything into it.

10. He shall not open on the Sabbath a vessel the cover of which has been luted on.

11. A man shall not carry on his person spices, going out or coming in on the Sabbath.

12. Within a house he shall not lift stone nor earth on the Sabbath day.

13. The nurse shall not carry an infant in arms, going out or coming in with it on the Sabbath.

14. A man shall not deal harshly with his slave or his maid or his hired servant on the Sabbath.

15. A man shall not deliver cattle of their young on the Sabbath day.

16. If a beast fall into a cistern or trap, a man shall not lift it out on the Sabbath.

17. A man shall not pass the Sabbath in a place near the gentiles.

18. A man shall not profane the Sabbath for the sake of gain.

19. If a human being fall into a tank of water or into a place of . . . no man shall fetch him up by means of a ladder or a rope or any implement.

20. No man shall bring upon the altar on the Sabbath anything except the Sabbath burnt-offerings, for so it is written, "aside from your Sabbaths."

The dietary laws afford other examples of the strict rules of the sect. ${ }^{43}$ Fish may be eaten only if, while still alive, they have been split open and drained of their blood; grasshoppers and locusts must be put alive into the water or the fire (in which they are to be cooked); honey in the comb is apparently prohibited. So, again, in a house in which a death has occurred, fixtures, such as nails and pegs in the walls, are unclean; and wood, stone, and dust are capable of contracting and communicating various kinds of uncleanness $(1215-18)$. The sect sees in these stricter distinctions between clean and unclean the superiority of its ordinances over those of other Jews, whom they regard as sinfully lax. The Pharisees are to them gross latitudinarians!

Oaths are to be taken only by the covenant and the curses of the covenant, that is, the vows by which the nembers of the sect bind themselves, on their admission to it, to live in confornity with its rule and submit to the authority of those set over them, 
and the curses invoked on such as violate these obligations. ${ }^{44}$ Oaths by God, whether under the name Aleph Lamed (El or Elohim) or Aleph Daleth (Adonai) are prohibited; ${ }^{45}$ nor is it permissible to mention in the oath the law of Moses; the formula of the oath is strictly sectarian ( $151 \mathrm{ff}$.). ${ }^{46}$ But, though the name of God is not used, "if a man swear and transgress the oath, he profanes the name" (15 3). Obligations voluntarily assumed under oath (vows) are to be fulfilled to the letter; neither redemption nor annulment seems to be allowed, unless to carry out the vow would be a transgression of the covenant.

Another point in which the sect is at variance with the great body of the Jews is the calendar. They represent the faithful remnant to whom God revealed the mysteries about which all Israel went astray, his holy sabbaths and his glorious festivals, and his righteous testimonies, and his true ways ( $312 \mathrm{ff}$.). The point of this appears when it is compared with Jubilees 1 14: "They will forget my law and all my commandments and all my judgments, and will go astray as to new moons and sabbaths and festivals and jubilees and ordinances" (cf. 6 34 ff., 23 19). The texts before us do not explain what the peculiarities of the sectarian calendar were, but inasmuch as the Book of Jubilees, under the title "The Book of the Division of the Times by their Jubilees and their Sabbatical Years," is cited as an authority for the exact determination of "their ends" (the coming crisis of history), it may be inferred with much probability that our sect had a calendar constructed on principles similar to that of the Jubilees, ${ }^{47}$ in which the seasons and festivals were not determined by lunar observations or astronomical tables, as among the Jews generally, but had a fixed place in a solar year. Such upsetting of the calendar is branded as heresy in Midrash Tehillim on Ps. 28 5: "They do not regard the work of the Lord,

${ }^{44}$ Similarly the Essenes, at their reception into the order, bound themselves by the "tremendous oaths" which Josephus describes, B. J. ii, 87.

${ }^{45}$ The oath by the Tetragrammaton included a fortiori.

${ }^{46}$ The Essenes excluded oaths altogether, except in the initiation of members. See also Slavonic Enoch 49 1; Philo, De spec. legibus ii, 1, and elsewhere (Charles, Secrets of Enoch, p. 65). Our sect recognizes judicial oaths (9 8 ff.) and imprecations (9 12), as well as vows under oath (16 $6 \mathrm{ff}$.).

${ }_{17}$ On the relation of the Jubilees to the sect, see further below, p. 359. 
nor the operation of his hands. . . 'The operation of his hands' means the new moons; as it is said, 'God made the two great lights,' and it is written, 'He made the moon for festival seasons.' ${ }^{8}$ These are the heretics who do not calculate (by the moon) the festival seasons and the equinoxes. "He will tear them down and not build them up.' He will tear them down, in this world, and not build them up, in the world to come." Perhaps the Boëthusians, who hired false witnesses to deceive the authorities about the appearance of the new moon, were not merely animated by a desire to harass the rabbis, but were partisans of some such calendar reform.

The organization of the sect furnished it an effective means of enforcing its rules by discipline. This organization is so peculiar that it must be described in some detail. Like the normal Jewish community, it consists of three classes, priests, levites, and Israelites, to whom as a fourth class may be added proselytes. In this order they are mustered and inscribed in the rolls of the camp. In some sense all the members of the sect are priests. Ezekiel 4415 is quoted and explained: "“The priests and the levites and the sons of Zadok who kept the charge of his sanctuary' [sic]. The priests are the exiles of Israel who migrated from the land of Judah and [the levites are] ${ }^{49}$ those who attached themselves to them; and the sons of Zadok are the chosen ones of Israel, men designated by name, who arose in the last days." Allegory apart, it appears that the priests were of the Zadokite line, but this legitimacy is assumed, not emphasized. Priests and levites formed part of every court of ten judges (see below, p. 351); and in every company of ten Israelites (the quorum of a religious assembly), a priest, well versed in the Book of Institutes, ${ }^{50}$ must be present, to whose words all must conform. If the priest does not possess the requisite qualifications, and a competent levite is at hand, it shall be ordained that all who enter the camp shall go out and come in at his orders. In a

${ }^{48} \mathrm{Cf}$. Jubilees 29 , God appointed the sun . . . for sabbaths, and months, and ieasts; and Jubilees 637 , the observation of the moon disturbs the calendar.

${ }^{49}$ It seems necessary to supply these words.

so "The book of hagu." The rendering 'Institutes' is not offered as a translation of the name, but as indicating the probable character of the work. See helow, p. $353 \mathrm{f}$. 
case of leprosy the priest shall come and stand in the midst of the camp and the Supervisor shall instruct him in the interpretation of the law; even if the priest be an ignoramus, it is he who must shut up the leper, for the decision belongs to them (13 $1 \mathrm{ff}$.). To a priest is assigned also the duty of taking the census of the commonalty; he who fills this office must be between thirty and sixty years old, versed in the Book of [Institutes and] in all the prescriptions of the law, to pronounce them according to their prescriptions (14 $3 \mathrm{ff}$.).

A much more important place in the organization is filled by an officer whose title (mebakker) signifies 'examiner,' 'inspector,' and may perhaps best be rendered 'Supervisor.' „s Every “camp," or settlement, of the sect had a Supervisor, and over these stood a "Supervisor of all the camps," who must be a man in the prime of life, between thirty and fifty years of age. To the Supervisor of the individual camp it belonged to instruct the community "in the works of God, and make them familiar with his wonderful deeds of might, and recount before them the things that happened long ago ...; and he shall have compassion on them as a father toward his children (13 $7 \mathrm{ff}$.)." 52 We have seen that he has even to instruct the priest in the rules for the diagnosis of leprosy. ${ }^{53}$ The admission of new members to the sect is also in his hands; no one is permitted to introduce a man into the

"I Dr. Schechter renders 'Censor,' and remarks, "Such an office, entirely unknown to Judaism, could only have been borrowed from the Romans." But the functions of the Inspector or Supervisor bear no resemblance to those of the Roman censors; and for the identity of the title the translator is solely accountable, not the constitution of the sect. Mr. Margoliouth talks loosely about dependence on Roman administrative models; it would be interesting to learn in what particulars. With the very large authority vested in the Supervisor may be compared that of the managers, or administrators (i $\pi \iota \mu \epsilon \lambda \eta \tau a i)$, among the Essenes, "without whose directions they do nothing"; though the functions of the managers in the Essene coenobite establishments were of course quite different from those of the Supervisors of our sect.

52 In the partly illegible lines that follow, his dealing with the congregation is compared with that of a shepherd with his flock.-Dr. W. H. Ward suggests that the title mebalker may be connected with Ezek. 3411 f., where the verb is used of a shepherd's looking out for his flock.

${ }^{53} \mathrm{As}$ in Mishna Yoma the High Priest has to be instructed by experts in the ritual of the Day of Atonement, and made to swear not to depart from his instructions. 
congregation without his consent. He examines the candidates in regard to their character and intelligence, their physical strength and courage, and their possessions, and enrolls each in his proper place in the lot ${ }^{54}$ of the camp (13 11 ff.). From the following badly defaced lines so much at least can be made out, that the Supervisor had extensive powers of control over the dealings of members of the sect with outsiders in the way of trade. He evidently had also a leading part in the administration of justice and the enforcement of the discipline of the sect, but the state of the text here denies us insight into the particulars.

Courts were constituted of ten members, ${ }^{55}$ chosen ad hoc from the congregation, four of the tribe of Levi and Aaron and six Israelites, all well versed in the Book of Institutes and in the Foundations of the Covenant, between twenty-five and sixty years of age. No man of more than sixty shall be a judge, "for on account of the unfaithfulness of mankind his days were shortened, and through the wrath of God on the inhabitants of the earth he bade to remove their understanding before they completed their days $(\mathbf{1 0} 4 \mathrm{ff}$.)." The rules relating to the competence of witnesses are strict. No one may testify against the accused in a capital case who is not a god-fearing man old enough to be included in the census (that is, at least twenty years of age, Exod. 30 14); nor shall a man's testimony be credited against his neighbor who is himself a wilful transgressor of any of the commandments, until he has conse to repentance (9 23-10 3). A peculiar provision is made for the case that a single witness (on whose testimony therefore conviction could not be had) sees a capital offence committed. He is to make known the facts to the Supervisor, who records the testimony in writing. If subsequently the offence is committed again in the presence of another witness, the same process is repeated; on a second repetition, the testimony of the three single witnesses combined suffices for conviction $(916 \mathrm{ff}) .{ }^{56}$

${ }^{54}$ Probably the lands belonging to the sect.

${ }^{55}$ That a court must consist of ten judges, the Karaites deduce from Ruth 42. So Anan quoted by Poznanski, Revue des études juives, vol. xlv, p. 67, and p. 69, n. $i$.

${ }^{36}$ This seems to be the meaning of the somewhat obscure passage. 
Besides the penalties of the Mosaic law, the sect has a formidable means of discipline in expulsion, or as it is called "separation from the Purity," which may in some cases be inflicted even on the testimony of one witness ( $\begin{array}{llll}9 & 21 & \mathrm{ff}\end{array}$.). Josephus vividly depicts the desperate straits into which those came who, for grave offences, were expelled from the Essene order; being unable to eat food not prepared by members of the order, they were exposed to starvation. This particular consequence would not follow separation from our sect; but the lot of the excommunicated man was evidently hard enough. "When his deeds come to light he is to be expelled from the congregation, as though his lot had never fallen in the midst of the disciples of God; according to his misdeeds men shall bear him in remembrance... until the day when he returns to take his place in the station of the men of perfect holiness. No man shall have any dealings with him in matters of property or work, for all the saints of the Most High have cursed him" (20 3 ff.); such have no part in the "house of the law"; their names are erased from the rolls of the congregation ( $2010 \mathrm{f}$.). They are not only cut off from the communion of saints in this world, but are doomed to extermination by the hand of Belial ( 8 I f., 19 14 f.). One who leads men astray and profanes the Sabbath and the festivals shall not be put to death, but shall be committed to the custody of men; 57 if he is cured of his error, they shall keep him for seven years, and afterwards he may come into the assembly (12 3 ff.). A member of the sect who seduces others to apostasy is more severely dealt with: "A man over whom the spirits of Belial have rule, ${ }^{58}$ and who advocates defection (Deut. 13 6), shall be judged according to the law of the necromancer and the wizard" (12 \& f.; cf. Deut. 18 9)..$^{59}$

The sect possessed the Jewish Scriptures. The books of the law are "the hut of the King" (i.e. the congregation) - the fallen hut which God had promised to raise up; "the pillar of your images" are the books of the prophets, whose words Israel despised. The founder of the sect, the star out of Jacob, is the

\footnotetext{
${ }^{67} \mathrm{It}$ is not clear whether imprisonment or surveillanee is meant.

${ }^{68}$ On the spirit of Belial (ruling over Israel) see Jubilees 120.

50 "Rebellion is as the sin of witcheraft," 1 Sam. 1523.
} 
interpreter of the law who came to Damascus ( 7 14 ff.). The authority of the Pentateuch is appealed to in support of the position of the sect in the matter of marriage and divorce; their peculiar statutes and ordinances are the true interpretation and application of the law of God. The prophets are frcquently cited, and allusions to passages in the prophets or reminiscences of their phraseology are much more numerous. There are similar reminiscences of the Psalms and of the Proverbs, and perhaps of other books among the Hagiographa. As regards the Old Testament scriptures, therefore, the sect stood on common ground with Palestinian orthodoxy. ${ }^{60}$ The formula of citation is peculiar; a quotation is usually introduced by the words "as he said," rarely "as God said"; or with the name of the sacred author, "as Moses said." Besides the Biblical books, we have a quotation from Levi-probably the Testament of that Patriarchintroduced by the same phrase as quotations from the Bible; and the reader is referred to the Book of Jubilees by name for an exact computation of the last times. There is nothing to indicate that the authority attributed to these writings was inferior to that of the Hagiographa. The canon of the "Scriptures" was not defined, even in the rabbinical schools, until the second century of our era, and in the sects nany books enjoyed high esteem which the orthodox repudiated. ${ }^{61}$

To a different class belong, apparently, the Book of Institutes, and the Foundations of the Covenant, in which the judges must be well versed. 'To every religious gathering of ten men or more belongs a priest well versed in the Book of Institutes. The title Foundations of the Covenant suggests a writing (or a fixed tradition) dealing with the obligations and duties of members of the sect. The name here rendered Book of Institutes, on the other hand, is obscure, ${ }^{62}$ but the fact that a knowledge of it is denianded

${ }^{60}$ In contrast to the Samaritans.

${ }^{61}$ In 818 ff., after saying, "Such will be the judgment of every one who despises the commandments of God, and he forsook them and they turned away in the stubbornness of their heart," A adds: "This is the word which Jeremiah spoke to Baruch the son of Neriah and Elisha to his servant Gehazi," referring probably to otherwise unknown apocryphal books. Johanneh and his brother, whom Belial raised up against Moses, are familiar figures of Jewish legend.

${ }^{62}$ The simplest explanation of the form would be to take it as an abstract noun of the type $f a^{\prime} l$, like $s a h u$; 'swimming' or $f^{\prime} l$, fu'l, like séku (n. pr.), tóhu, 
of the priest and of the judges makes it likely that it contained the "statutes and ordinances" of the sect, its peculiar definitions and interpretations of the law, often referred to as perush; in technical phrase, a collection of sectarian halakoth, such as is preserved in the second part of the texts before us, which seems to be derived from such a legal manual. The objection to committing halakah to writing which was long maintained in the rabbinical schools was not shared by the sects, and would be least likely to exist where the ordinances were not in theory a traditional law handed down from remote antiquity, but were attributed to an individual interpreter, the founder of the sect.

The sect had houses of worship, which a man in a state of uncleanness is forbidden to enter $(1122),{ }^{63}$ but nothing more is said about them, except that when the trumpets of the congregation are blown, the blowing shall follow or precede the service, and not interrupt it. It is a natural surmise that they answered to the synagogues both as places of worship and of religious instruction, such, for example, as the Supervisor is required to give. The name, Beth hishtahawōth, literally, 'house of bowing

bohu, etc., from the verb hagah (root hagro), 'reflect, give thought to something,' also 'read' (aloud), so that the noun might literally mean 'study,' equivalent to midrash, or perhaps 'reading.'--If the opinion which connects the sect with the Dositheans were tenable (see below, p. $360 \mathrm{ff}$.), another explanation of the name might be suggested by a passage in Abul-Fath's account of the origin of the Dositheans. He narrates that a son of the Samaritan high priest, named Zar'ah, a man preëminent for learning in his time, having been expelled from the eommunity for immorality, betook himself to Dositheus, who made him the chief of his sect. This man "wrote a book in which he vituperated all the Samaritan religious heads and set forth heresies." The words are, haja fïhì kul al'a'immetin wa' $a b d a^{6} a$ fì $h \bar{\imath}$. Inasmuch as the Arabic hajwun formally corresponds to the Hebrew hagu, the Book of Hagu in our texts might be identified with this controversial w riting of Zar'ah, the disciple of Dositheus. The Hebrew verb hagah is thought by Kohut (Aruch Completum, III, 177) to occur in Echa Rabbathi on Lam. 14 and 333 in the sense 'contemn, deride,' equivalent to the Arabic haja, 'lampoon, vituperate.' It might then be conjectured that Abul-Fath had heard of a Dosithean book of hagu (in Hebrew) and, taking the word in its Arabic meaning, evolved his description of the character of the work from this etymology.

${ }^{63}$ Some Karaite authorities, also, transferring to the synagogue the holiness of the temple, forbade a man in a state of uncleanness to enter the inner room of the synagogue (Nissi; see Winter und Wiunsche, Die jüdische Litteratur, vol. ii, p. 74). 
down' (in worship), is peculiar, and may have been chosen to distinguish these sectarian conventicles from the synagogues of regular Judaism, as the English nonconfornists of various stripes would not call their meeting-houses churches. It is possible that the prayers of the sect may have been accompanied by genuflections and prostrations such as, though unknown in the synagogue, have formed in all ages and religions a common feature of Oriental worship; but it is also possible that 'bowing down' simply stands by metonymy for worship, as is often the case with the corresponding Syriac verb, segad..$^{64}$

Sacrificial worship was also maintained. ${ }^{65}$ The City of the Sanctuary was eminently holy; sexual intercourse within its limits is forbidden, "defiling the City of the Sanctuary with their impurity" (beniddatham). ${ }^{66}$ To this city, probably, the sacrifices were brought to which there is frequent reference. "No one shall send to the altar burnt offerings or oblation, frankincense or wood, by a man who is unclean with any of the forms of uncleanness; for it is written, the sacrifice of the wicked is an abomination, but the prayer of the righteous is an acceptable oblation" (11 $18 \mathrm{ff}$.). On the Sabbath nothing is to be brought upon the altar except the Sabbath burnt offerings-that is, we may suppose, the stated daily burnt offerings with the supplementary Sabbath victims (13 17 f.; see Num. 28 1-10). Votive sacrifices are also men-

${ }^{64}$ The coincidence of the name with the Arabic masjid, "place of bowing down,' mosque, is hardly a sufficient reason for suspecting Moslem influence, as Dr. Schechter does, who thinks it possible that the word was introduced by a later (Falasha?) scribe as a substitute for the original term.-Elia Bashiatzi (Adereth Eliahu, p. 58), a Karaite writer of the 15th century, gives Beth hishtahawiya, together with Beth hakeneseth and Beth hamidrash, as the three names of the place of worship. Moslem influence can here hardly be questioned; in a later chapter Elia describes the postures of prayer quite after the Moslem pattern, alleging Biblical authority for all of them.

${ }_{65}$ The opinion that after Josiah's reform, or after the restoration of the temple by Zerubbabel and Joshua, Jerusalem was the only place where Jewish sacrifices were offered is refuted by an accumulating volume of evidence from various regions. See D. S. Margoliouth, Expositor, 1911, pp. $40 \mathrm{ff}$.

${ }^{66} \mathrm{Cf}$. the accusation against the orthodox Jews $\left(5_{6}\right.$ ): “They defile the Sanctuary in that they do not separate according to the law," etc.-It is possible that the prohibition quoted above applied, not to the inhabitants of the city, but to persons who visited it for the purpose of worship, as is the rule for pilgrims to Mecca. 
tioned; it is forbidden to vow to the altar anything that has been procured by compulsion; the priest shall refuse to receive such offerings (16 13 f.). There is nothing to indicate where this sanctuary was situated, further than the natural presumption that it was in the region of Damascus, where the sect had established itself. The priests have the precedence of all others in the community; in its registers their names are enrolled in the first rank. Their place in the courts and in the local religious community, and their duties in the examination of lepers, have already been mentioned. Those who officiated at the sanctuary had doubtless their legal toll from private sacrifices of every kind. Lost property for which no owner appears falls to the priests; a man who has appropriated such property shall confess to the priest, and all that he pays in restitution belongs to the priest, besides the ram of the trespass offering ( $913 \mathrm{ff}$.).

A charitable fund is provided by monthly payment of certain dues by members of the community to the Supervisor. From this fund relief is given by the judges to the poor and needy, to the aged, to the wanderer (?), to such as have fallen into captivity to foreigners, and others (14 $12 \mathrm{ff}$.).

The religious conceptions and beliefs of the sect present little that is peculiar. For God the name $E l$ is consistently used, without any epithets. Adonai is mentioned only to forbid its use in oaths. The only other name which occurs is the Most High (once, in the phrase "the saints of the Most High," that is, the members of the sect). There is repeated reference to the holy spirit: God, through his Anointed, made men know his holy spirit (2 12); the opponents of the sect, by blasphemous speech against the statutes of God's covenant, defiled their holy spirit $\left(\begin{array}{l}5 \\ 111\end{array}\right) ;{ }^{67}$ its nembers are warned not to defile his holy spirit by failing to observe the distinctions of clean and unclean which God has ordained ( $73 \mathrm{f}$.).

The "Prince of Lights (Urim)," through whom Moses and Aaron arise, is perhaps, as the contrast to Belial suggests, one of the highest angels. ${ }^{68}$ The destroying angels execute God's

${ }^{67}$ The holy spirit in them. Dr. Schechter adduces parallels in Jewish writings. Cf. Jubilees 121,23 , "Create in them a clean heart and a holy spirit."

${ }^{88} \mathrm{Dr}$. Schechter conjectures that the author wrote Sar ha-Panim, the Prince of the Presence, but the passages from Jubilees which he quotes in support of this opinion are hardly convincing. 
inescapable judgment on those who turned out of the way and despised the statute (26). The fall of the Watchers, which is a favorite subject in the apocalyptic literature, is referred to in 2 18. The chief of the evil spirits is Belial: he is "let loose" during the whole of the present dispensation; he lays snares for men and entraps them, especially in the three sins of fornication, unrighteous gain, and the defilement of the sanctuary (4 $15 \mathrm{ff}$.); his spirits rule over men and lead them to apostasy $\left(\begin{array}{ll}12 & \& \\ \text { f. }\end{array}\right)$; he also exterminates the faithless in the day of God's visitation (8 11 f.). Another name for the devil is Mastema (the commoner name in Jubilees), equivalent to Satan, "the adversary." The angel of Mastema ceases to follow a man who resolves to return to the law of Moses (16 f f.). According to Jubilees $108 \mathrm{f}$., 115 , Mastema had permission from God to employ some of his evil spirits to corrupt men and lead them astray.

Concerning the future life we read only that those who hold firmly to the law are "for eternal life," ${ }^{69}$ or, as it is elsewhere expressed, "have the assurance that they shall live a thousand generations." To a punishment of the wicked after death ${ }^{70}$ or to a resurrection of the dead there is no allusion whatever.

The moral teachings of the sect have been frequently touched upon above in speaking of their rules of life. Man is led into sin not only by the snares of Belial, but by his own sinful inclination and adulterous eyes ( 216 ; seemingly the yeser hara of the rabbis). It was through these that the Watchers fell; by them the generation of the flood sinned, and the sons of Jacob, and their descendants in Egypt and in Canaan, and brought judgment upon themselves $(2 \quad 14$ ff.). We have seen that the sect insisted upon monogamy, and perhaps rejected divorce altogether. Particular emphasis is laid in several places on the commandments, "thou shalt not take vengeance nor bear any grudge against the children of thy people," "thou shalt reprove thy neighbor and not bear sin because of him" (Lev. 1917,18$).^{71}$

${ }^{89}$ See Slavonic Enoch 42 5; cf. 9.

${ }^{70}$ So far as may be argued from silence, this is an important difference from Jubilees.

${ }^{71}$ See 7 2; cf. Slavonic Enoch 50 4: "When you might have vengeance, do not repay either your neighbor or your enemy. For God will repay as your 
Thus, at the beginning of the legal part of the book, the delivery of a fellow Israelite to the gentiles so that he is condemned by their law is said to fall under this prohibition, and further, "any man of those who enter into the covenant who brings up against his neighbor a matter not in the nature of a reproof before witnesses, but which he brings up in anger, or tells it to his elders to bring the man into disrepute, he is one that takes vengeance and bears a grudge." It is forbidden also to exact of another an oath except in the presence of the judges; he who does so transgresses the law which forbids a man to take justice into his own hands. Every one who enters into the covenant pledges himself not only not to rob the poor and make widows his spoil, but to love his neighbor as himself, to seek the welfare of his fellow, and to sustain the poor and needy. As regards the relations of the members of the sect to gentiles, it is forbidden to shed the blood of a gentile or to take aught of their property, "in order to give them no occasion to blaspheme" (12 $6 \mathrm{f}$.), that is, to prevent the profaning of God's name (15 3), a motive frequently urged in similar connection in the rabbinical writings. On the other hand, no man may sell to gentiles clean animals or birds, lest they offer them in sacrifice, nor grain, nor wine-naught of his possessions; nor shall he sell to them his slave or maid servant who have come with him into the covenant of Abraham (12 9 ff.). He may not pass the Sabbath in the neighborhood of gentiles. They are unclean, and garments they may have handled require purification.

No record of a schismatic body such as reveals itself in our texts is preserved in the early catalogues of Jewish heresies, nor have references to it been discovered in rabbinical sources. Like many sects, it exhibits the separatist inclination to outdo the orthodox in zeal for the letter and in strenuousness of practice, and it is not surprising that its interpretations of the law frequently agree with those of other strict-constructionists, such as Samaritans, Sadducees, Karaites; but these coincidences illustrate a common tendency rather than prove historical connection. The avenger in the day of the great judgment. Let it not be for you to take vengeance" (ed. Charles, p. 67); cf. Ecclus. 281. 
relation to the Book of Jubilees is, however, such as to show that there was some affinity between our sect and the circles in which that work originated. Jubilees is cited as authority on the last times; its calendar probably contains the secrets of God's holy sabbaths and glorious festivals about which all Israel was in error; the rules for the observance of the Sabbath in our book accord in many particulars with the injunctions in Jubilees $506 \mathrm{ff}$. (see also $\mathscr{2} 26 \mathrm{ff}$.); and various other resemblances might be pointed out, such as the preference for the unornamented word God (in Jubilees, God, or the Lord), in contrast with the many mouth-filling periphrases in Enoch; the holy spirit in men; the name Mastema for the adversary instead of Satan; Belial who ensnares men, and the spirits of Belial which rule over simners, besides others to which Dr. Schechter directs attention in his notes. The relation to the Testaments of the Twelve Patriarchs is less clear. The saying attributed to Levi $\left(\begin{array}{ll}4 & 15\end{array}\right)$ is not found in the Testament, and the other resemblances Dr. Schechter has noted are vague or belong to the commonplaces. The place of honor given to Judal in the Testaments, as we have them, is strikingly at variance with the attitude of our sect toward that tribe and its princes. The Levite Messiah of the Testaments is not precisely the same as the "Anointed from Aaron and Israel" in our book. In Jubilees also there are salient features, such as the more developed angelology and the form of the Messianic expectation, which hardly permit us to suppose that the book was a product of our sect, however highly it may have been esteemed by it.

The sect gives especial honor to the sons of Zadok, the ancient priesthood of the temple in Jerusalem (Ezek. 44 15, \& Chron. 31 10, Sirach 5112 Heb.); they are the chosen ones of Israel, men designated by name, who arose in the latter times (4 3); it was Zadok who brought to light the Book of the Law which no one had seen since the death of Eleazar and Joshua (5 5 ). The context of the latter passage would suggest that Zadok the contemporary of David is meant, who after the deposition of Abiathar becane Solomon's chief priest. ${ }^{72}$ The precedence given

72 That Zadok was the name of the "interpreter of the law," the founder of the sect, is a much less probable opinion; the name stands in no connection 
to the sons of Zadok may possibly have a side reference to the illegitimate high priests of Seleucid creation, such as Menelaus, thougl, if this were the intention, we should expect it to be emphasized.

The passages quoted are the only places in the book in which the name Zadok or the sons of Zadok appear, and they are certainly a very slender reason for describing the body which produced the book as a "Zadokite" sect, whatever meaning may be attached to the term. On the contrary, one of the outstanding things in the constitution of the sect is the predominance of the lay element. The Supervisor is a layman; laymen form the majority in every court; the Messiah is the "Anointed from Aaron and Israel." Whether the external testimony upon which Dr. Schechter relies for justification of the name is more adequate will be considered below.

Zadok and the sons of Zadok suggest the Sadducees, ${ }^{73}$ whose naine, according to the most probable explanation, designates them as descendants (or followers and partisans) of Zadok. Here again it is a question whether Zadok of David's time is meant, so that the Sadducees were the Zadokite aristocracy of the priesthood, as most nodern scholars think, or whether the name of the Sadducee sect is derived from a heresiarch of much later times, as the Jewish legend represents which makes Zadok, from whom the sect descends, a recalcitrant disciple of Antigonus of Socho, about the middle of the second century 13.c., contemporary, if we rightly interpret our texts, with the origin of the sect we are studying.

With the Sadducees, as we know them from the New Testament, Josephus, and rabbinical sources, our sect cannot well be identified. There is, however, a sect sometimes associated with the Sadducees, namely, the Dositheans, in whose teachings and customs Dr. Schechter finds such resemblances as lead him to surmise that the Dositheans were an offshoot of our sect. The

with the origin of the sect or its legislation, but with the bringing to light again of the Pcntateuch. The author cannot have supposed that the written law remained unknown till the second century B.C.; the reforms of Josiah, based on another recovery of the book by Hilkiah, would preclude such a notion.

73 The coincidence of names does not count for very much. Abul-Fath names two Samaritan "Zadokite" subsects among the later Dositheans alone. 
accounts of the Dositheans in writers of different ages and religious connections, from Origen and Epiphanius down to the Samaritan Chronicler Abul-Fath and the Moslem heresiographer Shahrastani, are notoriously confused and contradictory, ${ }^{74}$ so that many scholars have felt constrained to conclude that there was more than one sect of the name. The Fathers generally agree in describing the Dositheans as a Samaritan heresy, though Epiphanius and Philaster have it that the author of the heresy was by extraction a Jew. They frequently bring him into connection with Simon Magus, in the time of the Apostles. According to Origen, he gave himself out for the Messiah foretold by Moses; his followers had books of his, and legends pretending that he had not died, but was still alive somewhere. Other Fathers give no date for the rise of the heresy, but by coupling it with the Sadducees seem to imply that it was older than Christianity; thus (Pseudo)Tertullian (probably after Hippolytus) ${ }^{75}$ says that Dositheus the Samaritan was the first to reject the prophets as not inspired; the Sadducees, springing from this root of error, ventured to deny the resurrection also. From this Philaster probably drew the inference that Zadok, the founder of the Sadducees, was a disciple of Dositheus. The Samaritan and Moslem authors agree with the Fathers in treating the Dositheans as a Samaritan sect. Abul-Fath, a Samaritan writer of the fourteenth century, puts the beginnings of the sect in the first century B.c., at the time when the yoke of the Jews had been broken by the kings of the gentiles, and the Samaritans were able to return and restore their sanctuary, which had been destroyed by Simon and John Hyrcanus. ${ }^{76}$ The Moslem writer Shahrastani, in his

${ }^{74}$ See Hilgenfeld, Die Ketzergeschichte des Urchristenthums, 1884, pp. 155 ff.; Montgomery, The Samaritans, 1907, pp. $252 \mathrm{ff}$.

7 See also Epiphanius; the Sadducees were an offshoot from Dositheus.

${ }^{76}$ Not in the time of Alexander the Great, as Dr. Schechter has from Montgomery. Abul-Fath, indeed (and Adler's Chronicle after him), introduces this whole story before Alexander, and makes Simon a protégé of Darius; but the testimony that Dositheus appeared after the time of Hyrcanus, which, as a matter of Samaritan history, may be conceived to rest on tradition, is not to be set aside because, in fitting his Samaritan traditions into the framework of universal history, Abul-Fath is in error by two or three centuries about the date of Hyrcanus. This used to be understood; see, e.g., De Sacy, Chrestomathie arabe, vol. ii (1806), p. 209. 
learned work on Religions Sects and Philosophical Schools (first half of the twelfth century), gives substantially the same date: the founder of the Dositheans, who professed to be the prophet foretold by Moses, the star spoken of in the law, appeared about a century before Christ.

In this state of the evidence it is obrious that no argument can be based on the coincidence in time between the origin of the Dositheans and that of our sect. When the Fathers bring the names of Dositheus and Zadok into conjunction, it means no more than that they attributed certain errors to both Dositheans and Sadducees; just as the Talmudic legend which makes Zadok and Boëthus apostate disciples of Antigonus of Socho is but a mythological way of saying that Sadducees and Boëthusians were addicted to the same heresies concerning retribution, or as the coupling of Dositheus and Simon Magus means that both passed for Samaritan arch-heretics.

The first point of agreement between the Dositheans and our sect which Dr. Schechter notes is in the calendar. Abul-Fath says that the Dositheans did away with the computation of the almanac (tables of lunar coujunctions), making all their months exactly thirty days long, and (thus) annulled the correct festivals and the ordinance of the fasts and the affliction (Day of Atonement). ${ }^{77}$ The circle of thirty disciples, who, with a woman called Helena (Moon), formed the train of Dositheus, according to the Clementine Recognitions (ii, S) symbolized the days of the month. If our sect employed the calendar of the Book of Jubilees, as seems highly probable, they also had thirty-day months; but it would not follow that the system was original with them, nor that the Dositheans must have adopted it from them. There were, in fact, from very remote times, two years in use within the area of the ancient civilizations, a lunar-solar year, consisting of twelve lunar months of twenty-nine or thirty days each, with a thirteenth month added every two or three years to maintain approximate agreement with the solar year and make the months fall in the same seasons, and a solar year of three hundred and sixty-five days, divided into twelve months of thirty

${ }^{77}$ Epiphanius avers, on the contrary, that the Dositheans kept their festivals at the same time with the Jews. 
days each without regard to the lunations, and five extra days (epagomenae). The former was the system of the Babylonians and the Greeks, as well as the Jews; the latter was in use in Egypt from immemorial times until the Roman reforms. From the Egyptians it was borrowed by the Abyssinians; it was employed also for some centuries before and after the Christian era in the calendars of Gaza and Ashkelon. The Persians had the same system; the Yashts contain a liturgy for the thirty regents of the days of the month, the five extra days being assigned to the divine Gathas. Probably under Persian influences, this calendar was established in Armenia, Cappadocia, and other parts of Asia Minor. ${ }^{78}$

Jews and Samaritans not only lived in many of the lands of their dispersion among peoples who used the thirty-day month, but encountered this calendar in commercial centres on the very borders of Palestine with which they had close relations. The advantages of a system in which the festivals came on fixed dates, instead of shifting within wide limits, as they must in the lunarsolar year with its irregular intercalation, are obvious, ${ }^{79}$ and an attenipt to reform the Jewish calendar accordingly may have been made more than once and in more than one region. The peculiarity of the system of the Book of Jubilees is not the uniform length of the months, but the admission of only four extra days, thus making an even fifty-two weeks (36t days), which was of more concern to the author than the increased error of a whole day in the solar year. ${ }^{80}$ We do not know whether the Dositheans

${ }^{78}$ See Ideler, Handbuch der mathematischen und technischen Chronologie, vol. i, pp. $437 \mathrm{ff}$., 517; Ginzel, Handbuch der mathematischen und technischen Chronologie, vol. i, pp. $170 \mathrm{f}$., 287. On the calendar of Gaza, Schürer, Geschichte des jüdischen Volkes (3 ed.), vol. ii, pp. $88 \mathrm{f}$.

${ }^{79}$ We have experience of the inconvenience of this system in the wandering of Easter and the Christian festivals dependent on it; a reform by which Easter should come on a fixed date in the solar year has repeatedly been proposed, and a movement is now on foot in Europe to bring this about by agreement of governments and churches.

${ }^{80}$ The year of 364 days is found also in Enoch $72-82$, and (by the side of the true solar year of $3651 / 4$ and the lunar year of 354 days) in the Slavonic Enoch. The intercalary days are introduced one at the beginning of each quarter of the year (Enoch 75 1); this is also the method in Jubilees; see 623 . In effect this is equivalent to a year in which eight months have thirty days and four-those 
of Abul-Fath and the Sadducees of Kirkisani (of whom later) agreed in this point with Jubilees, or counted five extra days like the rest of the world. The former may be thought probable, but it cannot be assumed as certain. The year of 365 days is also found in the Greek Apocalypse of Baruch, c. 6 .

Dr. Schechter quotes Epiphanius ${ }^{81}$ on the Dositheans as saying, "some of them abstain from a second marriage, but others never marry"; and, although "the text is not quite certain on this point," 82 is inclined to perceive in the statement "at least an echo of the law of our sect prolibiting a second marriage as long as the first wife is alive." The passage in Epiphanius is more than obscure, and the text is for that reason suspected. The passage

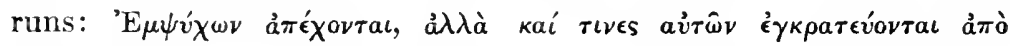


this may mean, it certainly is not, "some of them abstain from marriage after the death of their first wives," nor does anything in the context justify the large changes in the text which would be required to force this sense upon it. Casaubon's conjecture vi $\hat{\omega} \sigma \alpha \iota$ has nothing to commend it. The simplest solution of the difficulty would be to write $\sigma v \mu \beta \iota \hat{\omega} \sigma a \iota,{ }^{83}$ " some of them refrain from marital relations after having lived together, others preserve their virginity." Whether this emendation is right or not, it is clear that Epiphanius describes his Dositheans as a kind of Encratite ascetics, while the prohibition of polygany-whether contenporaneous or consecutive-by our sect has a totally different ground; of asceticism there is, indeed, no symptom in its ordinances.

Dr. Schechter thinks that the statement of Epiphanius quoted

in which the equinoxes and solstices fall-have thirty-one (Enoch 72 13, 19). It is not impossible that this system is implied in the chronology of the flood in Genesis; see B. W. Bacon, Hebraica, vol. viii (1891-1892), pp. 79-88, 124-189; Charles, Jubilees, p. 56 .

81 This is not the place to discuss the value of Epiphanius's testimony. His description of the Scribes and Pharisees at least admonishes to caution.

82 The text is certain enough, in the sense that all the manuscripts hitherto collated have the same reading.

${ }^{83}$ Nicetas, in reproducing Epiphanius's account of the Dositheans, bas $\tau \epsilon \kappa \nu \hat{\omega}-$ oal, "after having begotten children," which also agrees very well with the context. 
above that the Dositheans "abstain from eating living creatures" "may have some connection with the law in our text on p. 12, l. 11, which may perhaps be understood to imply that the sect forbade honey, regarding it as 'eber min hahai (a limb cut off from a living animal), which would agree with the testimony of AbulFath that they forbade the eating of eggs, except those which

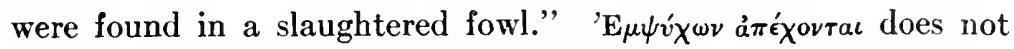
mean "abstain from eating living creatures," but "abstain from animal food," 84 while our sect certainly did not include vegetarianism among its eccentricities, any more than the depreciation of marriage.

Several authors describe the Dositheans as extravagant sabbatarians. Origen reports that their rule was, that in whatever place and in whatever posture the Sabbath found a man, there and thus he was to remain till its end. Abul-Fath gives a longer account of their Sabbath laws, which are much stricter than those of our texts. It was forbidden, for example, to feed domestic animals or give them drink on the Sabbath, they were to be provided on Friday with enough provender and water to last them through the Sabbath. Extreme sabbatarianism is, however, a sectarian propensity which does not have to be borrowed.

Dr. Schechter quotes Epiphanitis further as saying that the Dositheans "have no intercourse with all people because they detest all mankind," in which he thinks "we may readily recognize here the law of our Sect requiring the washing of the clothes when they were brought by a Gentile (because of the contamination), and the prohibition of staying over the Sabbath in the vicinity of Gentiles" (Introduction, pp. xxiii f.). What Epiphanius says is that the Dositheans agree with the rest of the Samaritans in the observance of circumcision and the Sabbath, and in avoiding contact with any one because they feel that all men (that is, all gentiles) are unclean. He had already described the customs of all the Samaritans: They wash themselves and their clothes in water when they come in contact with a foreigner; for they regard it as a defilement to come in contact with any one or even to touch

84 The familiar title of Porphyry's book on vegetarianism, II $\epsilon \hat{i} \dot{a} \pi \circ \chi \hat{\eta} s$ $\dot{\epsilon} \mu \psi \dot{v} \chi \omega \nu$, will occur to every one. Epiphanius himself explains the rord in Haer. 18, 1, "they (Nasaraei) thought it unlawful to eat meat." 
a man of another religion. ${ }^{85}$ It is, therefore, not a Dosithean peculiarity, but the general Samaritan usage which Epiphanius describes, and it is useless to search for remoter affinities.

The marked hostility to the patriarch Judah with which Eulogius, the Patriarch of Alexandria (died 607 A.D.), charges Dositheus ${ }^{86}$ is natural enough in a Samaritan heresiarch; in the same sentence Eulogius accuses him of scorning the prophets of God, which, again, is not peculiar to the Dositheans, but is the general Samaritan position. It has been remarked above (p. 353) that our sect gives especial honor to the books of the prophets "whose words Israel has despised"; and, however unfriendly the attitude of these seceders to the degenerate Judah of their time, there is no indication of animosity to the patriarch, as there is none in the Jubilees.

From a much later time Dr. Schechter has gleaned some notices of a sect of "Zadokites" in whose tenets also he recognizes resemblances to those of our sect. Kirkisani, a Karaite author of the tenth century, ${ }^{87}$ says: "Zadok was the first who exposed the Rabbanites and contradicted them publicly. He revealed a part of the truth, and composed books [a book] in which he frequently denounced the Rabbanites and criticised them. But he adduced no proof for anything he said, merely saying it by way of statement, except in one thing, namely, in his prohibition against marrying the daughter of the brother and the daughter of the sister. For he adduced as proof their being analogous to the paternal and maternal aunt." 88

This is a matter about which our sectaries are espccially fierce in their denunciations of the laxity of the orthodox. The argument they employ is the same which Kirkisani attributes to Zadok. It is, however, the obvious argument, if the principle of analogy be admitted in the interpretation of the law; it is com-

${ }^{85}$ Haer. 9, 3; cf. 30, 2: "The Ebionites, like the Samaritans, avoid touching an outsider." A still more extreme fastidiousness on this point is attributed by Josephus to the Essenes; cf. B. J. ii, 8, 10.

${ }^{86}$ Photius, Bibliotheca Codicum, cod. 280 (ed. Bekker, p. 285).

${ }^{87}$ The Kitab al-Anwār was published in 937 , not 637 , as by a misprint on p. xviii.

${ }^{88}$ Schechter's translation, Introduction, p. xviii. 
mon in the Karaite books, and is ascribed to the Samaritans also. ${ }^{89}$ Kirkisani also says that the Zadokites absolutely forbade divorce, which the Scripture permitted, agreeing in this with the Christians and with the Isawites, whose founders, Jesus and Obadiah of Ispahan, ${ }^{90}$ had likewise forbidden it. We are not told expressly that our sect prohibited divorce, but their prohibition of remarriage during the life of the divorced wife would have the same effect. Finally, Kirkisani says that the Zadokites fixed all the months at thirty days each, ${ }^{11}$ and that they did not count the Sabbath among the seven days of the celebration of the Passover and the Tabernacles, making the feast consist of seven days exclusive of the Sabbath. Substantially the same statements are made about the Zadokites by another Karaite author, Hadassi, who flourished in the middle of the twelfth century, and perhaps derived his information from Kirkisani.

What the "Zadokite" writings really were to which these authors refer is not known. It is certain, however, that both the Karaites and their opponents took them to be Sadducean works. In the passage about Zadok, part of which Dr. Schechter quotes (see above), Kirkisani says: "After the appearance of the Rabbanites (the first of whom was Simeon the Just), the Sadducees appeared; their leaders were Zadok and Boëthus. ... Zadok was the first who exposed the Rabbanites," etc. ${ }^{92}$ Zadok's disclosure of a part of truth was followed by the full discovery of the truth about the laws by Anan, the founder of the Karaites. Not only do the opponents of the Karaites stigmatize Anan and his followers as the remnants of the disciples of Zadok and Boëthus, but the older Karaites expressly claim this origin. Thus Joseph al-Basir (first half of the eleventh century) says that, in the times of the second temple, the Rabbanites, who were then called Pharisees, had the upper hand, while the Karaites, then known as Sadducees, were less influential. ${ }^{93}$ The Karaite author

${ }^{89}$ Schechter, p. xxxvii, n. 21.

${ }^{90}$ Founder of a Jewish sect which arose in Persia about the end of the seventh century.

${ }^{91}$ On this point see above, p. 362.

${ }^{92}$ Quoted in the original by Poznanski, Revue des études juives, vol. xliv (1902), p. 162, n. 2.

${ }^{93}$ Quoted by Poznanski, l. c., p. 170. 
of an anonymous commentary on Exodus preserved in manuscript in St. Petersburg ${ }^{94}$ polemizes against a disciple of Saadia, the great Malleus Karaeorum, about the proper way of determining the beginning of the months (and consequently the dates of the feasts), which the Rabbanites fixed by calculation of the conjunctions, while the Karaites depended on observation of the visible new moon. The ancients, he says, required evidence of the appearance of the new moon. ${ }^{95}$ Saadia, who mistakenly assumed that the beginning of the month had been determined astronomically from remote antiquity-the calendar was, in fact, of Sinaitic origin ${ }^{96}$-asserted that the taking of testimony about the appearance of the moon was an innovation occasioned by the contention of Zadok and Boëthus that the law required the beginning of the month to be determined by actual observation; witnesses were heard only to prove that observation confirmed the calculation. To this the author replies: "The book of the Zadokites (Sadducees) is well known, and there is no such thing in it as that man (Saadia) avers. In the book of Zadok are various things in which he dissents from the Rabbanites of the second temple with regard to sacrifices and other matters, but there is not a syllable of what the Fayyumite (Saadia) says." 97 Saadia himself appears not to have questioned the authenticity of the writings that went under the name of Zadok, with which he seems to have been acquainted, directly or indirectly, for in a passage quoted by Yefet ben 'Ali he says that Zadok had proved from the one hundred and fifty days in the story of the flood just the opposite of what the Karaites try to prove from them. ${ }^{98}$

${ }^{94}$ Harkavy attributed it conjecturally to Sahl ben Masliah; Poznanski, whom Dr. Schechter follows, thinks it more likely that the author was Hasan ben Mashiah.

${ }^{95}$ As the Karaites do. See e.g. Mishna, Rosh ha-Shana, $17 \mathrm{ff.}, 21 \mathrm{f}$.

${ }^{96}$ See Poznanski, Jewish Quarterly Review, vol. x (1898), pp. 159, 248, 273.

${ }^{97}$ Quoted in the original by Poznanski, Revue des études juives, vol. xliv, p. 176.-The point is that the "Zadokite" writings known to the author said nothing about fixing the beginning of the month by observation. Saadia doubtless based his assertion, not on anything he found in "Zadokite" books, but on Rosh ha-Shanah 22 a-b.

${ }^{98}$ Poznanski, l. c., p. 177; cf. also Jewish Quarterly Review, vol. x, pp. 246 ff.Saadia probably means that "Zadok" argued from the fact that the 150 days of Gen. 724,83 , make an even five months $(711,84)$, that each month had thirty 
Zadokite books thus meant, for all those from whom our information comes, Sadducean books; and so, in the sense that, whatever their age and origin, they contained substantially Sadducean teachings, most modern scholars, also, have understood the name.

The possibility that Sadducean writings from the beginning of the Christian era had survived to the Middle Ages cannot well be denied, especially in vicw of the preservation of the book of the unknown sect that forms the subject of our present study in copies as late as the tenth or eleventh century; and even if the book which the Karaites took for Sadducean was erroneously attributed to that sect, there is no sufficient ground for identifying it with the texts in our hands or for ascribing it to our sect. A thirty-day month, and the prohibition of divorce and of marriage with a niece, are much too slender a foundation to support so large an inference, and it is hardly legitimate to argue that if we had the entire book, of which only a part-or, according to Dr. Schechter, excerpts - is preserved, we might find other and more significant agreements.

Dr. Schechter has also remarked certain coincidences between the tenets of our sect and those of the Falashas, or Abyssinian Jews, whom, with Beer, he is disposed to connect in some way with the Dositheans. Their Sabbath laws resemble those in the Jubilees and in the texts before us; they also prohibit marriage with a niece; they have a tradition that the Pentateuch was brought to Abyssinia by Azariah, the son of Zadok (1 Kings 42 ); certain features of their calendar may possibly be related to that of the Zadokites as described by Kirkisani. Here, again, the correspondences are not numerous or distinctive enough to establish an historical connection.

Putting together these scattered indicia, Dr. Schechter arrives at a theory of the history and relations of the sect which must be given in his own words:-

We may, then, formulate our hypothesis that our text is constituted of fragments forming extracts from a Zadok book, known to us chiefly days (cf. Jubilees 527 ), while for the Karaites thirty days was only the extreme length of a lunar month. See Poznanski, Jewish Quarterly Review, vol. x, p. 241 . 
from the writings of Kirkisani. The Sect which it represented, did not however pass for any length of time under the name of Zadokites, but was soon in some way amalgamated with and perhaps also absorbed by the Dosithean Sect, and made more proselytes among the Samaritans than among the Jews, with which former sect it had many points of similarity. In the course of time, however, the Dosithean Sect also disappeared, and we have only some traces left of them in the lingering sect of the Falashas, with whom they probably came into close contact at an early period of their (the Falashas') existence, and to whom they handed down a good many of their practices. The only real difficulty in the way of this hypothesis is, that according to our Text the Sect had its original seat in Damascus, north of Palestine, and it is difficult to sec how they reached the Dositheans, and subsequently the Falashas, who had their main seats in the south of Palestine, or Egypt. But this could be explained by assuming special missionary efforts on the part of the Zadokites by sending their emissaries to Egypt, a country which was especially favourable to such an enterprise because of the existence of the Onias Temple there. The severance of the Egyptian Jews from the Palestinian influence (though they did not entirely give up their loyalty to the Jerusalem Sanctuary), prepared the ground for the doctrines of such a Sect as the Zadokites in which all allegiance to Judah and Jerusalem was rejected, and in which the descendants of the House of Zadok (of whom indeed Onias himself was one) represented both the Priest and the Messiah.

The evidence adduced in support of this ingenious hypothesis has already been examined in detail, and the results need only be summarized here: There is nothing in the book before us to warrant classing the men who made the new covenant in the land of Damascus as a Zadokite sect; ${ }^{99}$ neither the external nor the internal evidence suffices to identify the work quoted by Kirkisani as Zadokite (by which he and all the rest understood Sadducean) with the book before us; the connection of the sect with the Dositheans rests in great part on misunderstanding of the testimonies about the Dositheans-misunderstandings, it is fair to say, which are not all original with Dr. Schechter,-in part upon points of resemblance which are not distinctive enough to prove anything. Of the peculiar organization of our sect, which would be conclusive, there is no trace anywhere.

A much more sensational hypothesis was broached by Mr. G. Margoliouth in the Athenaeum for November 26, 1910, under 
the title, "The Sadducean Christians of Damascus." He takcs "the root" which God caused to spring from Israel and Aaron (1 7) for the same person who is subsequently called the Anointed one (Messiah), and distinguishes this figure from the Teacher of Righteousness, also called the Anointed one, who appeared twenty years later. "Both these Messiahs were dead when the document was composed, but they were both expected to reappear in the latter days."

The first of them, the Messiah descended from Aaron and Israel, in consequence of whose work "they meditated over their sin, and knew that they were guilty men," is John the Baptist. John's father was a priest, and though his mother also is said to have been of priestly descent, "this need not stand in the way of believing that there was a strain of non-priestly Israelite blood in the family." The Sadducees would naturally prefer a priestly Messiah to a Davidic one, and, when John won the recognition of the people as a prophet sent by God, it would not be strange if a priestly party acclaimed him as in some sense a Messiah, or anointed leader of the nation.

The other Messiah, the Teacher of Righteousness, must then be Jesus. That he appeared twenty years after John, so far from being an argument against this identification, would relieve the difficulty of trying to crowd John's whole history into little more than a year. "It is surely not necessary to defend the Lucan tradition on this point at all hazards, and it seems quite likely that the newly discovered document has at last given us the right perspective of events."

If these identifications are correct, the "man of scoffing," or Belial, ${ }^{100}$ who is sent to pervert the nation and turn it from the law, can be no other than the Apostle Paul, and it is noted for confirmation that "the period here assigned to his activity and that of his immediate following is about forty years, a space of time not far removed from the result of recent critical computation."

The New Covenant so often referred to in the texts is clearly to be connected with the identical conception and expression ${ }^{100}$ In "Belial is let loose," Mr. Margoliouth finds a witless pun on Paul's apostolic claims. 
in the New Testament, nor does it seem to be accidental that the Teacher of Righteousness is several times spoken of as the "only" or "unique" one.

Mr. Margoliouth presents his complete hypothesis as follows:-

The natural and apparently inevitable conclusion of the whole matter, therefore, is that we have here to deal with a primitive Judaeo-Christian body of people which consisted of priests and Levites belonging to the Boëthusian section of the Sadducean party, ${ }^{101}$ fortified - as the document shows-by a considerable Israelitish lay element, besides a real or contemplated admixture of proselytes. They acknowledged, as we have seen, John the Baptist, as a Messiah of the family of Aaron, and they also believed in Jesus as a kind of second (or, perhaps, as preeminent) Messiah whose special function it was to be a "Teacher of Righteousness." Paul they abhorred; and they strove with all their might to combine the full observance of the Mosaic Law, as they understood it, with the principles of the "new covenant," again as they understood it. On the destruction of the Temple by Titus, finding that it would not serve any good purpose to linger in Judaea, they determined to migrate to Damascus, ${ }^{102}$ intending to establish their central organization in that city, and to found communities of the sect in different parts of the neighboring country. It was at this juncture that the manifesto,

${ }^{101} \mathrm{Mr}$. Margoliouth is led to the opinion that they were Boëthusians by the obscure passage in 213 , which he interprets, "in the explanation of his name (sc. the Messiah's) are also their names,"-the name of the sect points mysteriously to the name of the Messiah. "Now the Boëthusians derived their name

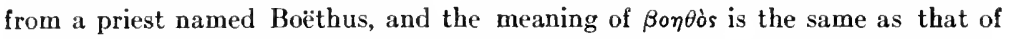
the Hebrew name represented by Jesus. The inference would be that the section of the Zadokite or Sadducees who adopted an attitude of belief toward John the Baptist and Jesus were none other than the Boëthusians (perhaps identical with the great company of believing priests of Acts 67 ), who not unnaturally liked to dwell on the identity of meaning between their names and that of the Teacher."-Boëthos, it may be remarked, is probably a Greek equivalent for the name Ezra, not for Jeshua.

${ }_{102} \mathrm{Mr}$. Margoliouth thinks that "the end of the destruction of the land," after which the migration to Damascus took place, "can hardly be anything else than the completion of the Roman conquest in A.D. 70." "At the end of the devastation of the land" means, however, not when the destruction was complete, but when the period of desolation was over. The phrase itself, therefore, is no more appropriate to Titus than to Nebuchadnezzar-or to Hadrian. Mr. Margoliouth does not say how he interprets the rest of the passage. Are the men who, at the end of the devastation of the land, "removed the boundary and led Israel astray," the great rabbis of the generations after the destruction of Jerusalem, and does the sequel, "and the land was laid waste because they spoke rebelliously against the commandments of God by Moses and against his holy Anointed one," refer to the war under Hadrian? 
bearing as it does unmistakable marks of personal touch, was composed by a leader of the movement.

No scholar who has made an independent study of the texts published by Dr. Schechter can have failed to consider the question whether these schismatics, with their "unique teacher," 103 their "new covenant," their "Supervisor," whose name and

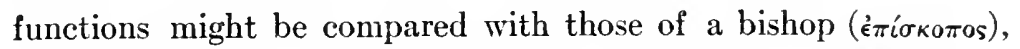
their loyalty to their dead leader, God's Anointed one (Messiah), who made them know his holy spirit, and their expectation of an Anointed one in the last times, their hostility to the Pharisees, can have been a Jewish Christian sect.

The more closely the documents are examined, however, the less tenable this conjecture appears. One feature of the sectarian eschatology which, if established, would afford the most striking coincidence with early Christian belief, namely, that the Messiah who died in the early days of the sect is to "reappear" (Margoliouth), or "rise again" (Schechter), has no support whatever in the text. ${ }^{104}$ The "new covenant" in the land of Damascus is plainly the obligation by which the members of the sect bind themselves to the organization, with its peculiar interpretations of the law and its distinctive observances. Neither in the terms of the covenant nor in the law itself is there anything that suggests Christian origin or influence. That "a man should love his neighbor as himself" is not peculiarly or even preëminently a Christian precept. The Testaments of the Twelve Patriarchs reiterate it; by the most orthodox rabbis it was recognized as the most comprehensive commandment in the law.

The things which the sect esteems of vital importance lie wholly in the sphere of the law; polemic zeal for a code which is at every point more rigorous than that of the Pharisees is the salient characteristic of both parts of the book. The moral precepts are the commonplaces of Judaism narrowed to a sectarian horizon. ${ }^{105}$

${ }^{103}$ As has been noted above, yāhid is sometimes rendered in the Greek Old

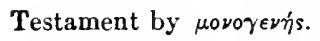

${ }^{104}$ See above, p. $3 \$ 1$.

${ }^{105}$ The commandment to love one's neighbor as himself, for example. In the contert of the covenant formula, in contrast to Jewish orthodoxy no less than to Christianity, the neighbor is not the fellow man, nor even the fellow Jew, but the fellow member of the schismatic church. 
The judgment of God is similarly circumscribed. It is not a judgment of the world or of the Jewish people, but of those who reject and controvert the legal interpretation of the sect, and of those who have fallen away from it.

The code of law which is the constituent principle of the sect and the reason for its existence was given it by its founder, the, Teacher of Righteousness. This unique teacher was not a prophetic reformer, but "the interpreter of the law who came to Damascus," "the legislator." The statutes he decreed are final; the sect "shall receive no others until the teacher of righteousness shall arise in the last times."

Mr. Margoliouth thinks that the "teacher of righteousness" to whom the sect attributed its institutions and laws was Jesus. The statement of this conjecture is its refutation. The rôle of a legislator is the last which the character and teaching of Jesus in the Gospels would suggest even to a sect in search of a founder. That he, whose disregard for the Pharisaic rules of Sabbath observance repeatedly got him into trouble, should, within a generation after his death, have been metamorphosed into the author of the sabbatical code in our texts, which outpharisees the Pharisees at every point, surpasses ordinary powers of imagination. The Christian Jews of the first century in Palestine, so far as we know anything about them, conformed in the matter of observance to the authority of the scribes and Pharisees, and alleged the express command of Jesus for this practice (Matt. 23 2). Early Christian heresies sometimes exhibit ascetic features reminding us of the Essenes; but none of ultra-legalistic tendency is known.

As our sect is very zealous for things which have no connection with Christianity, so on the other hand the texts disclose no trace of specific Christian beliefs or conceptions. For the Christian Jews of the first century, the belief that Jesus, who had been crucified under Pontius Pilate, was the Messiah of prophecy, that he had risen from the dead and ascended to heaven, whence he was presently to come in might and majesty, according to the vision of Daniel, to usher in the new era, was the pith and substance of their faith, the "heresy" by which they were separated from their countrymen, the focus of their polemic and 
apologetic in controversies with those who rejected their Messiah. It is impossible to imagine a writing as long as this, and imbued as strongly as this with a controversial spirit, proceeding from any Christian sect, in which there should not be so much as an allusion to any of these things; or that a sect which put John the Baptist in so high a place should not make something of baptism in the admission of members.

Apart from these general considerations, Mr. Margoliouth's identifications rest upon a palpable misinterpretation. On page 1 we read: "But because God remembered the covenant with the forefathers, he left Israel a remnant, and did not suffer them to be exterminated. And at the end of wrath . . . he visited them and caused to spring up from Israel and Aaron a root of his planting to inherit his land and to prosper on the good things of his earth." The italicized clauses prove beyond question that the "root" is not an individual, but is a collective designation for the first generation of the sect. ${ }^{106}$ The parallel passage on p. 5 says explicitly: "God remembered the covenant with the forefathers, and he raised up from Aaron men of insight and from Israel wise men, and he heard them, and they dug the well." "The well is the law, and they who dug it are the exiles of Israel who migrated to Judah and sojourned in the iand of Damascus." In the face of this perfectly plain meaning of the passage Mr. Margoliouth takes "the root" for the person designated in other places as "the Anointed from Aaron and Israel," who led the people "to recognize their wickedness and know that they were guilty men." 107 In this first Messiah he recognizes John the Baptist, and, consequently, in the Teacher of Righteousness who came after hin, Jesus. The point of correspondence is the relation between the forerunner and his successor. The text, however, as I have just showed, says nothing of a precursor of the teacher of righteousness; on the contrary, it was this teacher who first brought light to the generation which in the consciousness of its $\sin$ was

106 See above, p. 334.

${ }^{107}$ That the repentance of the people was brought about by the work of "the root" is not suggested in any way in the text; on the contrary, the only natural construction and interpretation of the passage would make the penitent generation the same with that which is called "the root." 
groping like the blind, and guided them in the way of God's heart. ${ }^{108}$

That by the "man of scoffing" the Apostle Paul is meant is for Mr. Margoliouth a corollary of the preceding identifications, and falls with them. The enemies of Paul were doubtless capable of calling him all sorts of hard names, but there is nothing in the epithets "scorner" and "liar," or in the doings attributed to this figure, which fits Paul better than any other false teacher and sower of discord, while the reference to the fate of the men of war who followed the "man of lies" seems quite inapplicable to Paul. ${ }^{109}$

That we should be unable to identify the Covenanters of Damascus with any sect previously known is not surprising. The three or four centuries in the middle of which the Christian era falls were prolific in sects and heresies of many complexions, as were the centuries following the rise of Islam. Through Philo, Josephus, the church Fathers, and the Talmud, we are acquainted with some of them; but it is probable that there were many others of which no reports have reached us. If we cannot, out of the collection at our disposal, put a label on our Covenanters, we may console ourselves with the reflection that here we know one Jewish sect from its own monuments, and that the texts in our hands, mutilated as they are, suffice to give us a much clearer notion of its pecnliarities than we get of most of the other sects from the descriptions which have come down to us.

Its affinities with various antipharisaic or antirabbinical parties, such as the Samaritans, the Sadducees, and, in later times, the Karaites, is obvious. It shared with all these a zeal for the letter and the literal interpretation, and a disposition to extend the law by analogy of principle, as a result of which their rules were in general much stricter than those of the Rabbis, who possessed

108 See above, p. 334.

${ }^{109}$ Gressmann is sure that this "man of lies" must be Bar Coziba (Bar Cocheba), the Messianic leader of the rebellion under Hadrian. He might have added that the contrast to the true star out of Jacob, the founder of the sect, would be peculiarly pertinent. The punning etymology, "Say not 'Star,' but "liar", (Echa Rabbathi on Lam. 2 2), is ascribed to the Patriarch Judah. 
in the theory of tradition and in their methods of exegesis the means of adapting the law to changed conditions, and who were also more disposed to give the precedence to the great principles of humanity in the law over its particular prescriptions when the two seemed to conflict. The organization of the sect, on the other hand, has no parallel within our knowledge. In view of the use of the name "camps" for the local communities, and the references to the "mustering" of the members, the "trumpets of the congregation," and the like, it may be surmised that the organization of Israel in the wilderness suggested the plan, and that the Supervisors were meant to correspond to the chiefs of the tribes (for instance, Num. 1 10), each having authority over a separate camp.

The sect seems to have perpetuated itself for a considerable time, otherwise this book would hardly have been preserved. It may perhaps be conjectured that it survived long enough to be gathered, along with numerous younger sects, into the capacious bosom of Karaism, of which it was in various points a precursor. Such an hypothesis would explain how it came about that copies of the book were made in the tenth century and later, we should then suppose by Karaite scribes. ${ }^{110}$

Dr. Schechter has laid all students of Judaisn under new obligations by the discovery and publication of these texts. They will join with their congratulations the hope that he may find yet other treasures among the accumulations of the Genizah.

${ }^{110}$ Perhaps the manuscripts may have been in the possession of some Rabbanite controversialist in Egypt, and thus found their way, like various Karaite writings, into the Genizah of the Synagogue. 



\section{Gaylord Bros.}

Makers

Syracuse, N.Y.

PAT. IAN. 21 . 1908

\section{DATE DUE}

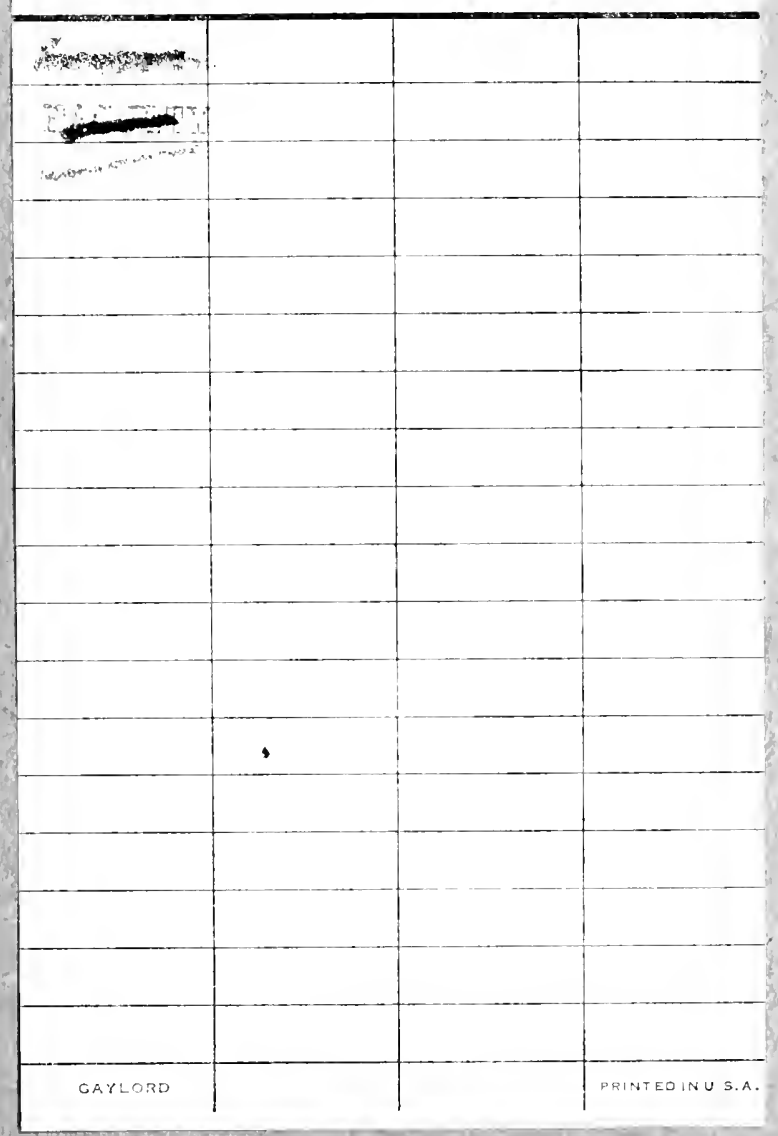




\section{| || || |||||||||||||| \\ 11012010109058}

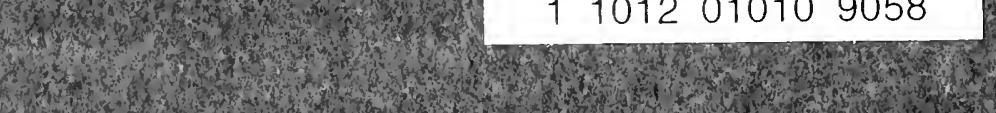

